\title{
ARTI PENTING PEMBERLAKUAN UU NO. 1/PNPS/1965
}

\author{
Hwian Christianto ${ }^{1}$
}

\begin{abstract}
Law Enforcement No.1/PNPS/1965 basically have a significant impact for religious life in Indonesia. Legal provisions explicitly provide protection for the actions of irregularities, defamation of religion also prohibits the spread of the teachings of atheism. In the development of the law No.1/PNPS./1965 assessed not according to the 1945 in terms of both formal and substantive judicial. Act petition was filed to clarify the constitutionality of laws that actually impeded No.1/PNPS/1965 religious life. Legal issues of interest in the issue of the relation of State and religion within the context of Pancasila and the 1945 Constitution. No.1/PNPS/1965 Act also provides three (3) types of crimes are very influential for Criminal Law.
\end{abstract}

Keywords: freedom of religion, the protection of the law, the state

\begin{abstract}
Abstrak
Pemberlakuan UU No.1/PNPS/1965 pada dasarnya memiliki dampak yang siginifikan bagi kehidupan beragama di Indonesia. Ketentuan hukum tersebut secara eksplisit memberikan perlindungan atas tindakan penyimpangan, penodaan agama juga melarang adanya penyebaran ajaran atheisme. Pada perkembangannya UU No.1/PNPS./1965 dinilai tidak sesuai dengan UUD 1945 baik dari segi juridis formil maupun materiil. Permohonan pengujian Undang-Undang pun diajukan untuk memperjelas konstitusionalitas UU No.1/PNPS/1965 yang justru dinilai menghambat kehidupan beragama. Isu hukum yang menarik dalam permasalahan tersebut tentang hubungan Negara dan agama di dalam konteks Pancasila dan UUD 1945. UU No.1/PNPS/1965 juga memberikan 3 (tiga) bentuk kejahatan yang sangat berpengaruh bagi Hukum Pidana.
\end{abstract}

Kata kunci: kebebasan agama, perlindungan hukum, negara

'Penulis adalah Dosen Fakultas Hukum Universitas Surabaya, Surabaya. 


\section{Pendahuluan}

Putusan Mahkamah Konstitusi Nomor 140/PUU-VII/2009 tentang Penolakan Pengujian Undang-Undang Nomor 1/PNPS/1965 tentang Pencegahan Penyalahgunaan dan/atau Penodaan Agama semakin menegaskan arti penting pemberlakuan UU No. 1/PNPS/1965 (selanjutnya disebut UU No.1/PNPS/1965). Putusan tersebut sekaligus memperkuat dasar keberlakuan yang sah secara konstitusional bagi UU No. 1/PNPS/1965 dan sekaligus pemberlakuan Pasal 156 bis KUHP. Dalam pokok permohonannya, pemohon bukan hanya mengajukan uji materiil namun juga uji formil atas keberlakuan UU No. 1/PNPS/1965. Permohonan pengajuan baik materiil maupun formil sebenarnya juga pernah dilakukan terhadap UU No.2/PNPS/1964 tentang Tata Cara Pelaksanaan Pidana Mati bagi terpidana mati yang juga diuji secara formil maupun materiil. Dikatakan sama karena produk hukum yang dimohonkan untuk diuji adalah undang-undang yang dibentuk pada masa demokrasi terpimpin yang dinilai tidak sesuai dengan cita-cita dan semangat UUD 1945. Selain itu dari sisi permohonan pengujian ternyata keduanya juga dimohonkan secara materiil dan formiil karena pemohon menilai dari kedua sisi tersebut, produk hukum ini bertentangan dengan konstitusi. Putusan Mahkamah Konstitusi terhadap dua perkara ini pun sama-sama menolak permohonan dan menguatkan produk hukum yang berasal dari masa demokrasi terpimpin itu. Jika putusan Mahkamah Konstitusi Nomor 21/PUU-VI/2008 semakin mengukuhkan tata cara pidana mati dengan ditembak sampai mati ${ }^{2}$ maka Putusan Mahkamah Konstitusi Nomor 140/PUUVII/2009 menekankan pentingnya partisipasi negara dalam menjaga kemurnian ajaran agama melalui pemberlakuan UU No. 1/PNPS/1965.

Hal menarik, bersamaan dengan pengajuan permohonan pengujian UU No. 1/PNPS./1965 saat itu diketahui adanya aliran Ahmadiyah yang menyebut dirinya sebagai bagian dari Agama Islam. Menanggapi aliran Ahmadiyah ini, MUI menyatakan aliran ini sebagai aliran yang dilarang ada di Indonesia karena ajarannya tidak sesuai dengan pokok-pokok ajaran agama Islam sebagaimana diajarkan dalam Al-Quran. Merespons hal ini Menteri Agama dengan mendasarkan diri pada UU No. 1/PNPS/1965 menyatakan aliran Ahmadiyah merupakan aliran yang dilarang dalam Agama Islam dan tidak mendapat perlindungan hukum.

Pandangan berbeda dikemukakan Pemohon pengujian UU No. 1/PNPS/1965 yang menilai keberlakuan Undang-undang ini sangat bertentangan dengan konstitusi

\footnotetext{
${ }^{2}$ Hwian Christianto, Tata Cara Pelaksanaan Pidana Mati bagi Terpidana Mati dalam Hukum Pidana, Jurnal Mahkamah Konstitusi, Vol. 6, Nomor 1 (April 2009), hal. 26 .
} 
baik dari segi formil (proses pembuatan) maupun segi materiil (muatan). Sorotan dari segi formil ditujukan pada situasi pembuatan UU No. 1/PNPS/1965 pada masa demokrasi terpimpin sebagai hasil Dekrit Presiden 1959 sehingga dinilai tidak sesuai dengan prinsip pembentukan Undang-undang sebagaimana diatur dalam UUD 1945. Sedangkan dari segi materiil, UU No. 1/PNPS/1965 dinilai sangat bertentangan dengan Konstitusi karena melanggar Hak Asasi Manusia untuk beragama secara bebas (Pasal 28E ayat (1), (2), Pasal 28I ayat (1) dan Pasal 29 ayat (2) UUD 1945).

\section{Rumusan masalah}

Permohonan Pengujian UU No. 1/PNPS/1965 terhadap UUD 1945 baik secara formil maupun materiil merupakan hal yang sangat penting bagi terjaminnya hak asasi untuk beragama. Hal yang perlu dikaji secara mendalam dari Putusan Mahkamah Konstitusi yang menolak pengujian UU No. 1/PNPS/1965 ini adalah:

1. Apakah UU No. 1/PNPS/1965 secara yuridis formil tidak melanggar Konstitusi?

2. Apakah ketentuan hukum tentang Pencegahan Penyalah-gunaan dan/atau Penodaan Agama tidak melanggar Pasal 28E ayat (1), (2), Pasal 28I ayat (1) dan Pasal 29 ayat (2) UUD 1945 sehingga penting untuk diberlakukan?

3. Apakah dampak yuridis pemberlakuan UU No. 1/PNPS/1965 bagi Hukum Pidana?

\section{Pembahasan}

\section{Latar belakang Pembentukan UU No. 1/PNPS/1965}

Latar belakang pembentukan UU No. 1/PNPS/1965 tidak terlepas dari suasana politik hukum pada tahun 1950-1966. Masa tersebut merupakan masa pembangunan hukum nasional yang berada dalam dua pilihan kebijakan yaitu tetap memberlakukan realism pluralisme (kebijakan dominan sejak zaman Kolonial) dan cita-cita Unifikasi (semangat persatuan dan kesatuan perjuangan revolusi Indonesia). ${ }^{3}$ Soetandyo menegaskan pertimbangan kebijakan hukum yang ada pada kurun waktu tersebut didasarkan oleh pertimbangan sosio-

${ }^{3}$ Soetandyo Wignjosoebroto, "Dari Hukum Kolonial ke Hukum Nasional: Dinamika Sosial Politik dalam Perkembangan Hukum di Indonesia", (Jakarta: RajawaliGrafindo, 1994), hal. 200. 
yuridis sekaligus politik-ideologik. ${ }^{4}$ Akibatnya setiap perundang-undangan yang terbentuk di masa itu lebih mencerminkan perjuangan untuk membentuk pembangunan hukum nasional. Hal tersebut terlihat dengan adanya 2 (dua) sub periode dengan dasar konstitusi berbeda, yaitu Sub periode 1950-1959 di bawah arahan Undang-Undang Dasar Sementara 1950 dan Sub periode 19591966 di bawah arahan Undang-Undang Dasar $1945^{5}$. UU No. 1/PNPS/1965 sendiri lahir dalam sub periode 1959-1966 yang berada dibawah arahan UUD 1945. Hanya saja terdapat kejanggalan dari pemberlakuan Sistem Demokrasi Terpimpin oleh Presiden Soekarno sebagai kelanjutan dikeluarkannya Dekrit Presiden 5 Juli 1959 melalui KEPRES No. 150/1959. Pemerintah pada saat itu memberikan beberapa definisi tentang demokrasi terpimpin diantaranya:

1. Demokrasi Terpimpin ialah demokrasi atau menurut istilah UUD 1945 "kerakyatan yang dipimpin oleh hikmat kebijaksanaan dalam pemusyawaratan perwakilan";

2. Demokrasi terpimpin bukanlah dictator, berlainan dengan demokrasi sentralisme, dan berbeda pula dengan demokrasi liberal, yang kita praktekan selama ini;

3. Demokrasi terpimpin adalah demokrasi yang cocok dengan kepribadian dan dasar hidup Bangsa Indonesia;

4. Demokrasi Terpimpin adalah demokrasi di segala soal kenegaraan dan kemasyarakatan, yang meliputi bidang-bidang politik, ekonomi dan sosial;

5. Inti daripada demokrasi terpimpin adalah pemusyawaratan tetapi suatu pemusyawaratan yang "dipimpin oleh hikmat kebijaksanaan" bukan oleh "perdebatan dan penyiasatan yang diakhiri dengan pengaduan kekuatan dan perhitungan suara pro dan kontra";

6. Demokrasi terpimpin adalah alat, bukan tujuan. ${ }^{6}$

Kekuasaan eksekutif pada masa itu memang sangat kuat jika dibandingkan kekuasaan lainnya (baik legislatif maupun yudisial). Mohammad T. Mansoer berpendapat "sistim pemerintahan di dalam Undang-Undang Dasar 1945 bukanlah Demokrasi Terpimpin. Setidak-tidaknya, tidak sama dengan demokrasi terpimpin. Sistimnya adalah Pemerintahan yang bertanggung-jawab,

${ }^{4}$ Ibid .

${ }^{5}$ Ibid.

${ }^{6}$ Ismail Suny, "Pergeseran Kekuasaan Eksekutif", (Jakarta: Aksara Baru, 1983), hal. 193-194. 
dalam hal ini oleh Presiden, kepada Majelis Pemusyawaratan Rakyat."7 Kondisi ini ditandai dengan dikeluarkannya beberapa produk hukum oleh Presiden seperti PNPS No. 1/1959 tentang Dewan Perwakilan Rakjat yang isinya menetapkan sementara DPR sebelum tersusun DPR yang sesuai dengan UUD 1945, PNPS No.2/1959 tentang Madjelis Permusjawaratan Rakjat Sementara yang menetapkan susunan MPR sementara sebelum MPR sesuai UUD 1945 terbentuk karena memang DPR juga belum terbentuk. Selanjutnya Mohammad T. Mansoer menegaskan bahwa tindakan Presiden tersebut memang kurang pada tempatnya "sebab dengan suasana yang demikian suasana yang "pyramidal" itu menunjukkan subordinasi mereka terhadap Presiden..."8 Menurut pemohon pengujian undang-undang, kedua produk hukum ini dikeluarkan Presiden dengan produk hukum Penetapan Presiden karena keadaan negara Indonesia pada saat itu dalam darurat. Unsur-unsur yang harus ada dalam negara dalam keadaan darurat menurut Jazim Hamidi dan Mustafa Lutfi meliputi:

1. Adanya bahaya negara yang patut dihadapi dengan upaya luar biasa;

2. Upaya biasa, pranata yang umum dan lazim tidak memadai untuk digunakan menanggapi dan menanggulangi bahaya yang ada;

3. Kewenangan luar biasa yang diberikan dengan hukum kepada pemerintah negara untuk secepatnya mengakhiri bahaya darurat tersebut, kembali ke dalam keadaan atau kehidupan normal;

4. Wewenang luar biasa dari hukum tata negara darurat itu adalah untuk sementara waktu saja, sampai keadaan darurat itu dipandang tidak membahayakan lagi. ${ }^{9}$

Mengenai bentuk-bentuk keadaan bahaya, Jimly Asshiddiqie menyebutkan: ${ }^{10}$

${ }^{7}$ Mohammad Tolchah Mansoer, "Pembahasan Beberapa Aspek tentang Kekuasaan-Kekuasaan Eksekutif dan Legislatif Negara Indonesia", (Jakarta: Pradnya Paramita, 1983), hal. 297.

${ }^{8}$ Ibid., hal. 298

9 Jazim Hamidi dan Mustafa Lutfi, Ketentuan Konstitusional Pemberlakuan Keadaan Darurat Dalam Suatu Negara, Jurnal Konstitusi, Volume 6, Nomor 1, (April 2009), hal. 46.

${ }^{10}$ Jimly Asshiddiqie, "Hukum Tata Negara Darurat", (Jakarta: RajawaliPers, 2007), hal. 68-70. 
1. Keadaan bahaya karena ancaman perang yang datang dari luar negeri (external aggression or foreign invasion);

2. Keadaan bahaya karena tentara nasional sedang berperang di luar negeri, seperti tentara Amerika Serikat berperang di Irak;

3. Keadaan bahaya karena pelanggaran yang terjadi di dalam, negeri atau ancaman pemberontakan bersenjata oleh kelompok separatis di dalam negeri, seperti pernah terjadi di masa DOM (Daerah Operasi Militer);

4. Keadaan bahaya karena kerusuhan sosial yang menimbulkan ketegangan sosial yang menyebabkan fungsi-fungsi pemerintahan konstitusional tidak dapat berfungsi sebagaimana mestinya;

5. Keadaan bahaya karena terjadinya bencana alam (natural disaster) atau kecelakaan yang dahsyat yang menimbulkan kepanikan, ketegangan,dan mengakibatkan mesin pemerintahan konstitusional tidak dapat berfungsi sebagaimana mestinya;

6. Keadaan bahaya karena tertib hukum dan administrasi yang terganggu atau menyebabkan mekanisme administrasi negara tidak dapat dijalankan sebagaimana mestinya sesuai keadaan yang berlaku. Keadaan yang demikian ini, misalnya, tercakup dalam keadaan yang dimaksud oleh Finer, Bogdanor, dan Rudden sebagai "internal state of emergency" (innerer notstand);

7. Keadaan bahaya karena kondisi keuangan negara dan kondisi administrasi negara yang tidak mendukung atau dimana ketersediaan keuangan negara tidak memungkinkan dilaksanakannya tugas-tugas pemerintahan oleh lembaga penyelenggara sebagaimana mestinya, sementara kebutuhan untuk bertindak sudah sangat genting dan mendesak untuk dilakukan;

8. Keadaan-keadaan lain dimana fungsi-fungsi kekuasaan konstitusional yang sah tidak dapat bekerja sebagaimana mestinya, kecuali dengan cara melanggar undang-undang tertentu, sementara keharusan untuk mengubah undang-undang dimaksud belum dapat dipenuhi dalam waktu yang tersedia.

Jika beberapa bentuk diatas dikomparasikan dengan keadaan negara Indonesia pada saat itu maka dijumpai perbandingan sebagai berikut: 


\begin{tabular}{|c|c|}
\hline Unsur Hukum Tata Negara Darurat & Informasi \\
\hline \multirow[t]{2}{*}{$\begin{array}{l}\text { Bahaya negara yang patut dihadapi } \\
\text { dengan upaya yang luar biasa }\end{array}$} & $\begin{array}{l}\text { - Tahun } 1965 \text { merupakan masa } \\
\text { transisi }^{11} \text { untuk melaksanakan UUD } \\
1945 \text { secara murni dan konsekuen }^{2}\end{array}$ \\
\hline & $\begin{array}{l}\text { - Pertentangan pendapat di } \\
\text { Konstituante yang terlalu lama, } \\
\text { tidak bermanfaat bagi masyarakat } \\
\text { dan sulit mencari penyelesaian } \\
\text { secara damai. }{ }^{12} \\
\text { - masih ada MPRS dan DPRS }\end{array}$ \\
\hline $\begin{array}{l}\text { Upaya biasa tidak memadai untuk } \\
\text { menanggulangi }\end{array}$ & $\begin{array}{l}\text { diperlukan satu tindakan untuk mengatur } \\
\text { kondisi tersebut dengan membentuk } \\
\text { kelengkapan baru }\end{array}$ \\
\hline $\begin{array}{l}\text { Adanya kewenangan yang luar biasa } \\
\text { yang diberikan oleh hukum }\end{array}$ & $\begin{array}{l}\text { Pasal } 12 \text { dan } 22 \text { ayat (1) UUD } 1945 \\
\text { memberikan hak khusus bagi Presiden } \\
\text { dalam keadaan bahaya atau kegentingan } \\
\text { yang memaksa }\end{array}$ \\
\hline $\begin{array}{l}\text { Berlaku hanya sementara sampai } \\
\text { keadaan normal }\end{array}$ & masa tersebut berlaku sementara \\
\hline
\end{tabular}

Sungguh pun negara dalam keadaan darurat tidak berarti Pemerintah bisa berbuat sekehendak hati tanpa ada batasan yang jelas. Pemerintah memang wajib memberikan pengaturan yang sifatnya mendadak tetapi tetap harus mempertimbangkan kepentingan masyarakat. Menurut Van Dullemen semua peraturan yang dikeluarkan pemerintah di masa negara darurat harus memenuhi beberapa persyaratan sebagai berikut:

1. Kepentingan tertinggi negara yakni adanya atau eksistensi negara itu sendiri;

2. Peraturan darurat itu harus mutlak atau sangat perlu;

\footnotetext{
${ }^{11}$ Soetandyo Wignjosoebroto, Loc. Cit..

${ }^{12}$ Ismail Suny, Loc. Cit., hal. 192.
} 
3. Noodregeling itu bersifat sementara, provosoir, selama keadaan masih darurat saja, dan sesudah itu, diperlakukan aturan biasa yang normal, dan tidak lagi aturan darurat yang berlaku;

4. Ketika dibuat peraturan darurat itu, Dewan Perwakilan Rakyat tidak dapat mengadakan sidang atau rapatnya secara nyata dan sungguh. ${ }^{13}$

Keempat syarat ini bersifat kumulatif sehingga peraturan pemerintah yang dibuat pada saat negara dalam keadaan darurat haruslah diuji berdasarkan keempat syarat tersebut. Termasuk didalamnya UU No. 1/PNPS/1965 yang memang dibuat dalam kurun waktu negara dalam keadaan darurat. Jika dilihat dari latar belakang pembentukan UU No. 1/PNPS/1965 seperti dijelaskan pada bagian Konsiderans Penetapan Presiden bahwa penetapan Presiden tersebut dibuat dalam rangka pengamanan Negara dan masyarakat, cita-cita revolusi nasional dan pembangunan semesta menuju pencegahan penyalahgunaan atau penodaan agama dan untuk pengamanan revolusi dan ketentraman masyarakat. Setidaknya terdapat dua alasan mendasar pembentukan penetapan presiden ini yaitu:

1. Pengamanan Negara dan revolusi Nasional terkait dengan pencegahan penyalahgunaan atau penodaan agama;

2. Pengamanan revolusi dan ketenteraman masyarakat.

Dari kedua alasan diatas, sangat tampak tujuan utama dikeluarkannya penetapan presiden ini semata-mata untuk mendukung pengamanan revolusi sedangkan pencegahan penyalahgunaan atau penodaan agama merupakan salah satu faktor penunjang tercapainya revolusi Nasional. Hal tersebut menunjukkan bahwa Penetapan presiden tersebut selalu menempatkan Dekrit Presiden sebagai sumber hukum padahal MPRS dan DPRS sudah terbentuk. Mohammad T. Mansoer menilai hal tersebut sebagai suatu tindakan yang "tidak ada rationya". ${ }^{14}$ Penetapan Presiden tersebut kemudian menimbulkan pertanyaan tentang hubungan antara Negara dan agama, apakah terdapat satu kewenangan negara untuk mencampuri urusan agama dan sebaliknya. Oemar Seno Adji menjawab hal tersebut dengan mengatakan: 1996), hal. 7.

${ }^{13}$ Herman Sihombing, "Hukum Tata Negara Darurat di Indonesia", (Jakarta: Djambatan,

${ }^{14}$ Mohammad T. Mansoer, Loc. Cit., hal. 314. 
Bagaimanapun, Negara Hukum kita berdasarkan Pancasila, yang bukan Negara Agama, berdasarkan - "Einheit" antara Negara dan Agama dan yang tidak menganut "separation" dalam batas-batas yang tajam dan strict, seperti dianut oleh Negara-negara Barat dan Negara-negara Sosialis yang bahkan mengikut-sertakan sanctie pidana pada azas "separation" tersebut, ... ${ }^{15}$

Indonesia sebagai negara yang berdasar atas ke-Tuhanan Yang Maha Esa sekaligus negara hukum harus memandang kedua bidang ini sebagai satu kesatuan yang saling mendukung antara satu dengan yang lainnya. Konsepsi negara hukum membawa konsekuensi bagi Indonesia untuk mengatur segala tatanan kehidupan masyarakat dengan hukum demi terciptanya ketertiban dan kepastian hukum. Wirjono Prodjodikoro menegaskan pentingnya peran serta Negara berdasarkan Pasal 29 ayat (1) UUD 1945 untuk menjamin keharusan setiap warga negara Indonesia untuk beragama. ${ }^{16}$ Sedangkan negara berdasarkan ke-Tuhanan Yang Maha Esa tidak berarti Indonesia merupakan Negara Agama sehingga mendasarkan dirinya pada salah satu agama tetapi agama merupakan nilai moral dan pengakuan hati nurani rakyat adanya rahmat Allah yang maha kuasa, negara ini ada. Pendapat senada diberikan Soewoto dengan menyebutkan bahwa Indonesia merupakan negara seculer yang tidak secularistik yang berarti tidak mendasarkan diri pada satu agama tertentu atau semua agama tetapi berwawasan kebangsaan. ${ }^{17}$ Urusan agama memang pada dasarnya merupakan urusan pribadi tiap individu tetapi dalam relasinya dengan kebebasan beragama dan kerukunan umat beragama, Negara harus berinisiatif memberikan perlindungan hukum. Selanjutnya Oemar Seno Adji memaparkan 3 (tiga) pandangan tentang pentingnya perlindungan agama: ${ }^{18}$

1. Friedensschutz theory, memandang "der religiosce interkon fessionelle Feriede" sebagai kepentingan Hukum yang harus dilindungi;

${ }^{15}$ Oemar Seno Adji, "Perkembangan Hukum Pidana dan Hukum Acara Pidana Sekarang dan di Masa Jang akan Datang", (Jakarta: Pantjuran Tujuh, 1983), hal. 50.

${ }^{16}$ Wirjono Prodjodikoro, "Azas-Azas Hukum Tata Negara di Indonesia", (Jakarta: Dian Rakyat, Cetakan Kelima, 1983), hal. 160.

${ }^{17}$ Soewoto, Perlindungan Hukum terhadap Agama dan Aliran Kepercayaan, Jurnal Yuridika, No.2 , Tahun XI, (Maret-April 1996), tanpa nomor halaman.

${ }^{18}$ Oemar Seno Adji, Op.Cit. 
2. Gefühlsschutz-theorie yang hendak melindungi rasa keamanan sebagai "das heiligste Innenleben der Gesammtheit", seperti dikemukakan oleh Binding, dan

3. Religionsshutz-theori, dikemukakan oleh Kohler dan Kahl, yang melihat Agama sebagai kepentingan hukum yang harus diamankan oleh Negara berdasarkan "das Kulturgut der Religion und der ungeheuren Idealismus, der aus ihr fürreine grösse Menge von Menschen hervorgeht".

Indonesia sendiri dengan pengaturan kejahatan terhadap agama lebih cenderung menerapkan Religionsshutz-theori karena tujuan pengaturan UU No.1/PNPS/1965 untuk mengamankan kepentingan hukum atas agama yang dianut di Indonesia. Oemar Seno Adji juga menekankan pentingnya aturan "blasphemy" tersebut mengingat "Indonesia dengan Pancasila dengan sila Ketuhanan Yang Maha Esa sebagai causa prima, tidak memiliki suatu "afweer" terhadap serangan kata-kata mengejek terhadap Tuhan". ${ }^{19}$ Soedarto menjelaskan kondisi pada waktu itu dengan banyaknya kasus penodaan agama seperti Al-Qur'an disobek-sobek dan dinjak-injak, Nabi Muhammad dikatakan "nabi bohong", pastor dihina karena tidak kawin, ketoprak dengan judul "Paus Gandrung" dan munculnya aliran-aliran kebathinan kecil yang menamakan dirinya agama tetapi praktek keagamaannya sangat menyimpang dari aturan agama yang sudah ada. ${ }^{20}$ Pengaturan kejahatan terhadap agama dalam UU No.1/PNPS/1965 seharusnya ada tetapi harus lebih disempurnakan dengan perumusan yang sesuai dengan sifat Negara yang berke-Tuhanan Yang Maha Esa. ${ }^{21}$ Hal senada juga ditegaskan UU No. 6 Tahun 1969 bahwa materi UU No.1/PNPS/1965 perlu dituangkan dalam undang-undang baru dengan penyempurnaan yang diperlukan.

\section{Aspek Yuridis Formiil UU No. 1/PNPS/1965}

Keberadaan penetapan presiden di masa itu memang benar-benar amat dibutuhkan mengingat bermunculan aliran-aliran atau organisasi-organisasi

19 Oemar Seno Adji, "Herziening-Ganti Rugi, Suap, Perkembangan Delik", Cetakan Kedua, (Jakarta: Erlangga, 1984), hal. 297.

20 Soedarto, "Hukum Pidana dan Perkembangan Masyarakat: Kajian terhadap Pembaharuan Hukum Pidana", (Bandung: Sinar Baru, 1983), hal. 78-79.

${ }^{21}$ Oemar Seno Adji, Op. Cit. 
kebathinan/kepercayaan masyarakat yang bertentangan dengan ajaran-ajaran dan hukum Agama yang telah ada (Penjelasan angka 2 UU No. 1/PNPS/1965). Sebagaimana ditegaskan oleh Oemar Seno Adji, keberadaan Pasal 156a KUHP merupakan hal yang "condito sine qua non" harus ada dalam kehidupan hukum negara Indonesia. ${ }^{22}$ Hal yang menarik dari penjelasan angka 2 UU No. 1/PNPS/1965 yang menilai bahwa aliran-aliran, atau organisasi kebathinan/kepercayaan ini ternyata "telah menimbulkan hal-hal yang melanggar hukum, memecah persatuan Nasional dan menodai Agama." Jika demikian Penetapan Presiden ini memang di satu sisi memiliki tujuan utama untuk mengatasi secara represif aliran-aliran atau organisasi kebathinan kepercayaan yang dinilai tidak sesuai dengan ajaran pokok Agama yang ada. Oleh karena itu, judul Penetapan Presiden ini sebenarnya sangat tidak tepat karena hanya menekankan upaya pencegahan (preventif) terhadap aliran-aliran agama yang mungkin timbul dikemudian hari. Konsekuensi yuridisnya, seharusnya setiap aliran atau organisasi kebathinan dan kepercayaan sebelum peraturan ini dibuat dinyatakan tetap berlaku dan dilindungi secara hukum, mengingat penetapan presiden ini dibuat bukan untuk "mengurangi" atau "menguji" aliran/organisasi kepercayaan yang ada (Religionschutz-theori). Pemahaman ini cukup sesuai jika dirujuk Penjelasan Pasal 1 UU No. 1/PNPS/1965 yang pada dasarnya tidak melarang agama atau aliran kepercayaan lain seperti Yahudi, Zarazustrian, Shinto, Theosim, asalkan tidak bertentangan dengan peraturan ini. Konsekuensi yuridisnya, Indonesia tidak hanya mengakui beberapa agama saja seperti Islam, Kristen, Katolik, Hindu, Budha dan Kong Cu (Penjelasan Pasal 1 UU No.1/PNPS/1965) tetapi agamaagama lain juga diakui.

Disinilah inkonsistensi Penetapan Presiden No.1 Tahun 1965 tampak dengan jelas. Bahwa di satu sisi Penetapan Presiden mencegah timbulnya aliran atau kepercayaan baru namun di sisi lain membuka kesempatan bahkan perlindungan hukum bagi agama baru. Sangat dimungkinkan suatu aliran yang pada dasarnya bersumber pada salah satu ajaran pokok agama yang sudah ada tetapi menafsirkan pandangannya secara berbeda mengajukan perlindungan sebagai agama baru yang dilindungi. Justru keadaan inilah yang berpotensi menimbulkan perpecahan bahkan konflik serius di masyarakat. Sekalipun pemerintah mempunyai kebijakan untuk mengarahkan badan/aliran kebathinan kearah pandangan yang sehat dan kearah Ke-Tuhanan Yang Maha Esa (TAP

\footnotetext{
${ }^{22}$ Oemar Seno Adji, Op. Cit., hal. 304.
} 
MPRS No. II/MPRS/1960, Lampiran A Bidang I, angka 6) tetap membuka kesempatan bagi aliran yang pada dasarnya menyimpang dari ajaran agama yang ada untuk menjadi agama baru dan dilindungi oleh hukum.

Keberlakuan UU No.1/PNPS/1965 sebagai sebuah norma hukum yang dianggap berlaku oleh masyarakat dapat ditinjau melalui 4 kajian ${ }^{23}$ sebagai berikut:

1. Keberlakuan Filosofis

Keberlakuan sebuah peraturan hukum dinilai dari sejauh mana peraturan hukum tersebut memiliki kesesuaian dengan nilai-nilai filosofis (nilainilai suci dan luhur) yang merupakan sumber kehidupan kenegaraan. ${ }^{24}$ UU No.1/PNPS/1965 (termasuk di dalamnya Pasal 156a KUHP) memang dibentuk pada masa demokrasi terpimpin namun untuk memahami keberlakuannya dari segi filosofis harus dibandingkan dengan nilai-nilai Pancasila. Materi UU No.1/PNPS/1965 pada dasarnya sangat kental dengan perlindungan hukum atas nilai-nilai KeTuhanan Yang Maha Esa sebagaimana tercantum dalam Sila Pertama Ketuhanan Yang Maha Esa. Hal tersebut dapat dikaji dari Pasal 1 dan 4 yang memberikan perlindungan hukum terhadap penyimpangan ajaran agama, penghinaan/ permusuhan terhadap agama serta atheisme.

2. Keberlakuan Juridis

Sebuah peraturan perundang-undangan harus dilihat apakah sesuai dengan teknis yuridis dalam pembuatannya sehingga dapat diterapkan sebagai norma hukum yang berlaku. ${ }^{25}$ Keberlakuan Juridis lebih melihat pada proses pembentukan sebuah aturan hukum sebelum diberlakukan oleh pihak yang berwenang. Disinilah permohonan perngujian UU No.1/PNPS/1965 secara formill di ajukan kepada Mahkamah Konstitusi karena dianggap menyalahi proses pembentukan peraturan perudangundangan sebagaimana ditetapkan oleh UUD 1945. Perlu dipahami bahwa UU No. 1/PNPS/1965 berasal dari Penetapan Presiden (Penpres) No. 1 Tahun 1965 yang dikeluarkan oleh Presiden dengan beberapa

\footnotetext{
${ }^{23}$ Jimmly Asshidiqqie, "Perihal Undang-Undang", (Jakarta: Konstitusi Press, 2006), hal. 240.

${ }^{24}$ Ibid., hal. 241.

${ }^{25}$ Ibid., hal. 242.
} 
pertimbangan sebagaimana tercatat dalam Konsideran UU No.1/PNPS/1965. Latar belakang historis pembentukan Penetapan Presiden pada masa itu sebenarnya didasarkan pada Dekrit Presiden 5 Juli 1959 dan kondisi negara Indonesia pada saat itu yang kacau. Presiden berinisiatif mengeluarkan produk hukum Penetapan presiden untuk mengatur beberapa hal yaitu PNPS No.1/1959 tentang DPR Sementara, PNPS No.2/1959 tentang MPR Sementara, PNPS No.3/1959 tentang DPA Sementara yang lebih lanjut pada tahun 1965 dikeluarkan PNPS No.1 Tahun 1965. Terkait dengan diberlakukannya TAP MPRS No.XX/MPRS/1966 tentang Tata Urutan Perundang-undangan Republik Indonesia memang produk hukum Penetapan Presiden tidak secara eksplisit diatur. Mengingat materi PNPS No.1/1965 pada Pasal 4 memberikan suatu instruksi penambahan Pasal 156a pada Kitab UndangUndang Hukum Pidana maka secara yuridis formiil hanya produk hukum berupa Undang-Undang-lah yang diperlukan bukan Penetapan Presiden. Perkembangan selanjutnya, UU No. 6 Tahun 1969 ternyata memberikan pengesahan sekaligus pemberlakuan pada PNPS No.1/1965 sebagai Undang-undang sehingga disebut UU No.1/PNPS/1965. Tujuan pengujian PNPS No.1/1965 tersebut tidak lain merupakan wujud pelaksanaan UUD 1945 secara murni dan konsekuen serta didasarkan pada TAP MPRS No. XIX/MPRS/1966 tanggal 5 Juli 1966 dan TAP MPRS No. XXXIX/MPRS/1968 tanggal 27 Maret 1968 (vide Konsideran UU No. 6 Tahun 1969). Sejak tanggal 5 Juli 1969 sebenarnya baru dapat dikatakan penyisipan Pasal 156a KUHP berlaku karena kekuatan Undang-Undang No. 6 Tahun 1969. Tidak hanya sampai disini saja, UU No.6 Tahun 1969 sebenarnya memberikan penegasan untuk melakukan penyempurnaan terhadap materi Penetapan Presiden tersebut dengan tetap memperhatikan nilai-nilai Pancasila. Kesimpulannya, UU No.1/PNPS/1965 telah melalui proses pengujian dan ditetapkan sebagai Undang-undang yang sah menurut UU No.6 Tahun 1969 sehingga sama sekali tidak bertentangan dengan UUD 1945 (Pasal 22 ayat (2) UUD 1945). 


\section{Keberlakuan Politis}

Keberlakuan suatu produk hukum harus didukung oleh fraksi-fraksi kekuatan politik yang ada. ${ }^{26}$ Keberlakuan Politis UU No.1/PNPS/1965 harus dilihat dalam 2 tahapan, yaitu pada saat PNPS No.1/1965 dikeluarkan dan pada saat PNPS No.1/1965 menjadi Undang-undang oleh UU No. 6 Tahun 1969. Pembentukan PNPS No.1/1965 memang di latarbelakangi permasalahan politik yang tidak menentu. Jika sebelumnya telah timbul beberapa kelompok yang ingin mendirikan negara agama (Pemberontakan DI/TII, Pemberontakan Kartosuwiryo, misalnya) maka latar belakang historis Penetapan Presiden Nomor 1 Tahun 1965 lebih menunjukkan adanya ancaman terhadap persatuan dan kesatuan bangsa dengan isu agama. Penjelasan umum UU No.1/PNPS/1965 menyebutkan:

Sebagai dasar pertama ke-Tuhanan Yang Maha Esa bukan saja meletakkan dasar moral diatas Negara dan Pemerintah, tetapi juga memastikan adanya kesatuan Nasional yang berazas keagamaan....Dari kenyataan teranglah bahwa aliran-aliran atau Organisasi Kebathinan/Kepercayaan masyarakat yang menyalahgunakan dan/atau mempergunakan Agama sebagai pokok, pada akhir-akhir ini bertambah banyak dan telah berkembang ke arah yang sangat membahayakan Agama-agama yang ada.

Untuk mencegah berlarut-larutnya hal-hal tersebut di atas yang dapat membahayakan persatuan bangsa dan Negara, maka dalam rangka kewaspadaan Nasional, dan dalam Demokrasi Terpimpin dianggap periu dikeluarkan Penetapan Presiden sebagai realisasi Dekrit Presiden 5 Juli 1959 ...

Penjelasan tersebut merupakan gambaran kebijakan politik pemerintah yang pada saat itu berlaku demokrasi terpimpin. Keberlakuan secara politik pun harus dilihat dalam konteks demokrasi terpimpin yang mengakui setiap tindakan presiden sebagai yang utama. Seperti diungkapkan oleh Mohammad T. Mansoer bahwa pada masa tersebut Presiden Soekarno masih besar seperti pada masa-masa terakhir berlakunya UUDS $1950 .^{27}$ 
Sedangkan pada tahap pemberlakuan PNPS No.1/1965 sebagai UndangUndang harus dipahami keberlakuan politis UU No. 6 Tahun 1969. Undang-undang tersebut pada dasarnya dibentuk dengan mendasarkan diri pada 2 Ketetapan Majelis Permusyawaratan Rakyat Sementara yaitu TAP MPRS No. XIX/MPRS/1966 tanggal 5 Juli 1966 dan TAP MPRS No. XXXIX/MPRS/1968 tanggal 27 Maret 1968 yang bertujuan untuk melaksanakan UUD 1945 secara murni dan konsekuen. Pembentukan UU No.6 Tahun 1969 bisa dikatakan telah disepakati oleh fraksi-fraksi politik pada saat itu meskipun dibentuk secara sementara oleh PNPS No.2/1959.

4. Keberlakuan Sosiologis

Aturan hukum harus ditinjau dari keberlakuan secara empiris melalui 3 kriteria yaitu kriteria pengakuan, kriteria penerimaan, dan kriteria fantisitas hukum. ${ }^{28}$ Pemberlakuan UU No.1/PNPS/1965 dari kriteria penerimaan dapat dilihat dari rasa terikat masyarakat untuk tidak melakukan perbuatan-perbuatan yang dilarang dalam UU No.1/PNPS/1965. Banyaknya kasus penodaan agama menjadi bukti bahwa masyarakat merasa terikat dengan ketentuan hukum tersebut. Selain itu kasus-kasus penodaan agama yang terjadi juga menjadi bukti akan tidak adanya penerimaan masyarakat terhadap aturan hukum tersebut. Terakhir tentang kriteria fantisitas hukum, UU No.1/PNPS/1965 cukup efektif dalam menanggulangi penyimpangan ataupun penodaan agama yang dalam banyak kasus terjadi. Berdasarkan tiga kriteria tersebut diperoleh kesimpulan bahwa keberlakuan sosiologis UU No.1/PNPS/1965 belum tercapai dengan baik sehingga terhadap aturan hukum tersebut sangat perlu dilakukan penyempurnaan.

Terkait dengan masalah apakah peraturan yang dibuat pada masa negara dalam keadaan darurat itu hanya berlaku sementara saja, mengingat produk hukum Penetapan Presiden tidak dikenal dalam tata urutan perundang-undangan Indonesia maka diperlukan langkah pengujian aturan hukum terhadap UUD 1945 apakah berlaku ataukah tidak. UU No.6 Tahun 1969 menjawab hal tersebut dengan memberlakukan PNPS No.1/1965 menjadi UU No. 1/PNPS/1965. Kesimpulannya, PNPS

\footnotetext{
${ }^{27}$ Mohammad Tolchah Mansoer, Loc. Cit., hal. 297.
}

${ }^{28}$ Jimly Asshidiqqie, Op. Cit., hal. 243-244. 
No.1/1965 memang berlaku untuk sementara tetapi diberlakukan sebagai Undang-undang melalui UU No. 6 Tahun 1969.

\section{Pengaturan tentang Pencegahan Penyalah-gunaan dan/atau Penodaan Agama tidak melanggar Hak Asasi Manusia}

UU No. 1/PNPS/1965 tentang Pencegahan Penyalahgunaan dan/atau Penodaan Agama pada dasarnya memang bertujuan melindungi kehormatan agama. Hal agama dan beragama merupakan hak asasi yang dimiliki manusia sebagaimana ditegaskan dalam Pasal 18 Deklarasi Umum Hak Asasi Manusia yang menyatakan:

Everyone has the right to freedom of thought, conscience and religion; this right includes freedom to change his religion or belief, and freedom, either alone or in community with others and in public or private, to manifest his religion or belief in teaching, practice, worship and observance.

Adalah hak asasi bagi tiap manusia sebagai individu untuk beragama dan beribadah sesuai dengan agamanya tanpa pengekangan. Hal senada juga diatur dalam Pasal 18 International Covenant on Civil and Political Rights (ICCPR) yang menegaskan:

1. Everyone shall have the right to freedom of thought, conscience and religion. This right shall include freedom to have or to adopt a religion or belief of his choice, and freedom, either individually or in community with others and in public or private, to manifest his religion or belief in worship, observance, practice and teaching.

2. No one shall be subject to coercion which would impair his freedom to have or to adopt a religion or belief of his choice.

3. Freedom to manifest one's religion or beliefs may be subject only to such limitations as are prescribed by law and are necessary to protect public safety, order, health, or morals or the fundamental rights and freedoms of others.

4. The States Parties to the present Covenant undertake to have respect for the liberty of parents and, when applicable, legal guardians to ensure the religious and moral education of their children in conformity with their own convictions. 
ICCPR lebih merinci hak beragama ini ke dalam hak untuk memilih agama secara pribadi, larangan bagi pihak manapun untuk mengurangi hak memilih agama ini, hak untuk memanifestasikan agamanya (hak untuk beribadah) dan kewajiban negara untuk menghormati pendidikan beragama dari keluarga dan anak. Pada point keempat inilah terdapat satu pembatasan bagi negara (pemerintah) untuk mencampuri urusan agama.

Bagi bangsa Indonesia sendiri hak untuk beragama ini sudah menjadi hak pokok yang diakui sejak lama. Pengakuan atas hak untuk beragama selalu diatur dalam tiga konstitusi yang pernah berlaku di Indonesia. Undang-Undang Dasar Tahun 1949 Pasal 18 menyatakan: ${ }^{29}$

Setiap orang berhak atas kebebasan pikiran, keinsyafan batin dan agama; hal ini meliputi pula kebebasan bertukar agama atau keyakinan, begitu pula kebebasan menganut agamanya atau keyakinannya, baik sendiri maupun bersama-sama dengan orang lain, dengan jalan mengajarkan, mengamalkan, beribadat, mentaati perintah dan aturanaturan agama, serta dengan jalan mendidik anak-anak dalam iman dan keyakinan orang tua mereka.

Pasal 18 UUD 1950 menegaskan "Setiap orang berhak atas kebebasan agama, keinsyafan batin dan pikiran".

Pembukaan UUD 1945 secara eksplisit menegaskan dasar kedaulatan rakyat Indonesia kepada "Ketuhanan Yang Maha Esa...." Diikuti pengaturan Pasal 28E dan Pasal 29 yang menegaskan:

Pasal 28E

1) Setiap orang bebas memeluk agama dan beribadat menurut agamanya, memilih pendidikan dan pengajaran, memilih pekerjaan, memilih kewarganegaraan, memilih tempat tinggal di wilayah negara dan meninggalkannya serta berhak kembali.

2) Setiap orang berhak atas kebebesan meyakini kepercayaan, meyakini pikiran da sikap sesuai dengan hati nuraninya.

29 H.A.K. Pringgodigdo, "Tiga Undang-Undang Dasar", Cetakan Keenam, (Jakarta: Pembangunan, 1989), hal. 106-107. 
3) Setiap orang berhak atas kebebasan berserikat, berkumpul, dan mengeluarkan pendapat.

Pasal 29

1) Negara berdasar atas Ketuhanan Yang Maha Esa.

2) Negara menjamin kemerdekaan tiap-tiap penduduk untuk memeluk agamanya masing-masing dan untuk beribadat menurut agamanya dan kepercayaannya itu.

Hak beragama merupakan hak yang dilindungi Konstitusi sehingga harus dijaga keberlakuannya. UU No. 39 Tahun 1999 tentang Hak Asasi Manusia, Pasal 22 yang menyatakan:

1) Setiap orang bebas memeluk agamanya masing-masing dan untuk beribadat menurut agamanya dan kepercayaannya itu.

2) Negara menjamin kemerdekaan setiap orang memeluk agamanya masingmasing dan untuk beribadat menurut agamanya dan kepercayaannya itu.

Kebebasan untuk memeluk agama dan kemerdekaan beribadat menurut agama dan kepercayaan pada dasarnya merupakan salah satu bentuk hak asasi manusia yang pada pelaksanaannya tidak boleh mengganggu hak asasi manusia lainnya. Pasal 28J UUD 1945 memberikan kewajiban dan pembatasan atas hak dan kebebasan hak asasi manusia. Pelaksanaan hak asasi manusia wajib menghormati hak asasi manusia orang lain dan wajib tunduk pada pembatasan yang diberikan Undang-undang. Berdasarkan Pasal 28J ayat (2) UUD 1945 tersebut Negara melakukan pembatasan atas hak asasi manusia untuk beragama dan beribadat menurut agamanya.

Hanya saja pengaturan berbeda diberikan dalam UU No. 1/PNPS/1965 yang menegaskan pencegahan penyalahgunaan dan penodaan Agama yang secara khusus mengatur perlindungan terhadap agama dan ajarannya bukan pada kebebasan untuk beragama. Secara sepintas jika diperhatikan rumusan Pasal 1 UU No,1 /PNPS/1965:

Setiap orang dilarang dengan sengaja di muka umum menceritakan, mengajarkan atau mengusahakan dukungan umum, untuk melakukan penafsiran tentang sesuatu agama yang dianut di Indonesia atau melakukan kegiatan-kegiatan keagamaan yang menyerupai kegiatankegiatan keagamaan dari agama itu; 
Penafsiran dan kegiatan-kegiatan mana yang menyimpang dari pokokpokok ajaran agama itu.

maka dapat diperoleh pemahaman bahwa UU No.1/PNPS/1965 ini memberikan larangan terhadap pihak atau aliran atau organisasi kepercayaan yang melakukan penyimpangan pada ajaran pokok agama yang dianut di Indonesia (6 agama yang diakui menurut Penjelasan Pasal 1 UU No.1/PNPS./1965). Hal pokok yang dilarang oleh UU No.1/PNPS/1965 adalah penyimpangan ajaran agama yang dianut di Indonesia. Baik itu berupa penafsiran ajaran agama, melakukan kegiatan agama yang serupa dengan agama yang dianut, dll. Untuk menentukan ada atau tidaknya penyimpangan dalam hal ini di butuhkan standar baku untuk dijadikan dasar penilaian. Uniknya UU No.1/PNPS/1965 tidak merujuk langsung kepada siapakah wewenang penilaian ada/tidaknya penyimpangan itu diberikan. Penjelasan Pasal 1 UU No.1/PNPS./1965 hanya memberikan patokan bahwa penilaian itu didasarkan atas "asal tidak melanggar ketetuan-ketentuan yang terdapat dalam peraturan ini atau peraturan perundangan lain." Tetap terdapat ketidakjelasan batasan dan ukuran sampai sejauh mana suatu aliran atau kepercayaan/kebathinan itu dapat dikatakan menyalahgunakan dan atau menodai agama yang sudah ada. Oleh karena itu sangatlah penting diatur lebih lanjut batasan dan dasar penilaian berikut pihak yang berwenang untuk menilai ada atau tidaknya penyimpangan berupa penodaan atau penyalahgunaan terhadap agama yang dianut masyarakat Indonesia. Menurut penulis, karena di Indonesia terdapat lembaga-lembaga keagamaan yang menaungi tiap agama dan mempunyai kewenangan dari pemerintah (Majelis Ulama Indonesia/MUI, Persatuan Gereja Indonesia (PGI), Konferensi Wali Gereja Indonesia (KWI), Perwalian Umat Budha Indonesia (WALUBI) dan Persatuan Hindhu Dharma Raya (PERSAHI) maka untuk menilai ada atau tidaknya penyimpangan seharusnya diberikan kepada lembaga-lembaga keagamaan ini. Kemungkinan adanya campur tangan negara terhadap pelarangan atau pembatasan agama melalui lembaga-lembaga keagamaan tersebut dapat dihindarkan.

Apakah dengan demikian materi UU No. 1/PNPS/1965 melanggar UUD 1945 secara materiil? Perlu diperhatikan bahwa ketidak jelasan pengaturan Penetapan Presiden ini memang diperlukan aturan pelaksana yang lebih jelas karena jika tidak akan berdampak pada pelanggaran hak atas kepastian hukum masyarakat ( Pasal 28D ayat (1) UUD 1945). Secara normatif, UU No.1/PNPS/1965 terutama Pasal 1 justru memberikan perlindungan bagi masyarakat Indonesia untuk memperoleh ajaran agama yang benar sesuai dengan ajaran pokok dari Kitab Suci masing-masing agama. Memang pada dasarnya penerapan ajaran agama diperoleh dari kegiatan penafsiran terhadap KItab Suci tetapi untuk dapat dinilai sahih (benar atau tidaknya) 
hasil penafsirsan ini tetap harus merujuk pada Kitab Suci itu sendiri. Tidak dapat diungkiri dalam praktek beragama, banyak dijumpai berbagai macam hasil penafsiran terhadap Kitab Suci yang berbeda satu dengan lainnya. Akan tetapi harus dipahami dasarnya, bahwa perbedaan itu harus tetap berada dalam konteks ajaran yang benar dan tidak boleh menyimpang dari ajaran yang pokok. Bagi seseorang yang akan memahami suatu suatu teks Kitab Suci pun tidak boleh sembarangan menggunakan metode penafsiran. Seseorang ini harus benar-benar memahami dasar penafsiran yang benar sesuai dengan kontekstual Kitab Suci masing-masing agamanya. Implikasinya, setiap orang dapat melakukan pemahaman terhadap ajaran agamanya dengan tetap mendasarkan diri pada pokok-pokok ajaran yang benar seperti tercantum dalam Kitab Suci-nya.

Sejak di berlakukan tanggal 27 Januari 1965, sudah terdapat beberapa kasus yang melibatkan penerapan UU No. 1/PNPS/1965 seperti tampak dalam data berikut ini: ${ }^{30}$

\begin{tabular}{|c|c|c|c|}
\hline No. & $\begin{array}{c}\text { Nama } \\
\text { Kasus/Pelaku }\end{array}$ & Posisi Kasus & $\begin{array}{c}\text { Pertimbangan dan } \\
\text { Putusan Hakim }\end{array}$ \\
\hline 1. & $\begin{array}{l}\text { Penodaan } \\
\text { Nama Nabi } \\
\text { Muhammad } \\
\text { saw. } \\
\text { Pelaku: } \\
\text { Arswendo } \\
\text { Atmowiloto }\end{array}$ & 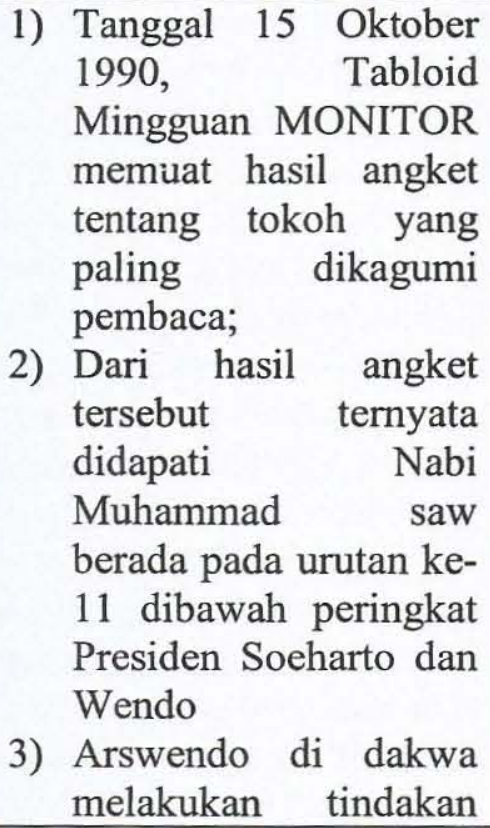 & 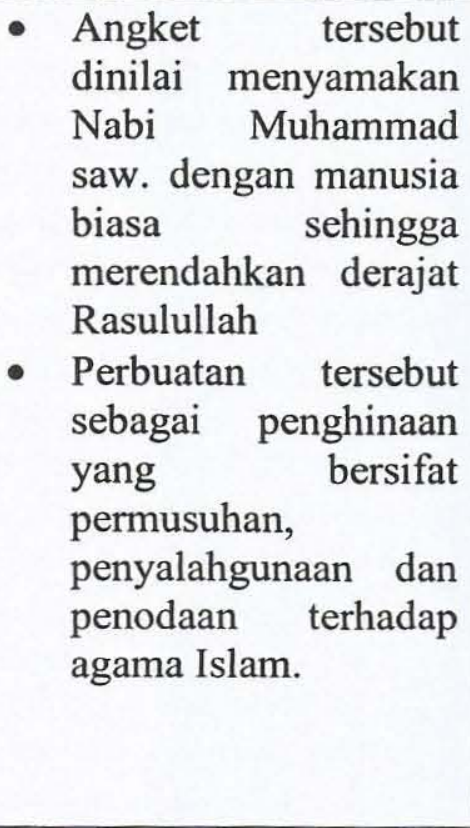 \\
\hline
\end{tabular}

30 Sumber Intenet <http://www.mahkamahkonstitusi.go.id/putusan/putusan_sidang_Putusan \%20PUU\%20140_Senin\%2019\%20April\%202010.pdf>, diakses tanggal 2 Oktober 2010. 


\begin{tabular}{|c|c|c|c|}
\hline & & $\begin{array}{lr}\text { penodaan } & \text { agama } \\
\text { seperti } & \text { dituduhkan } \\
\text { Pasal 156a KUHP }\end{array}$ & \\
\hline 2. & $\begin{array}{l}\text { Kasus Lia } \\
\text { Eden } \\
\text { Pelaku: LIa } \\
\text { Aminuddin }\end{array}$ & 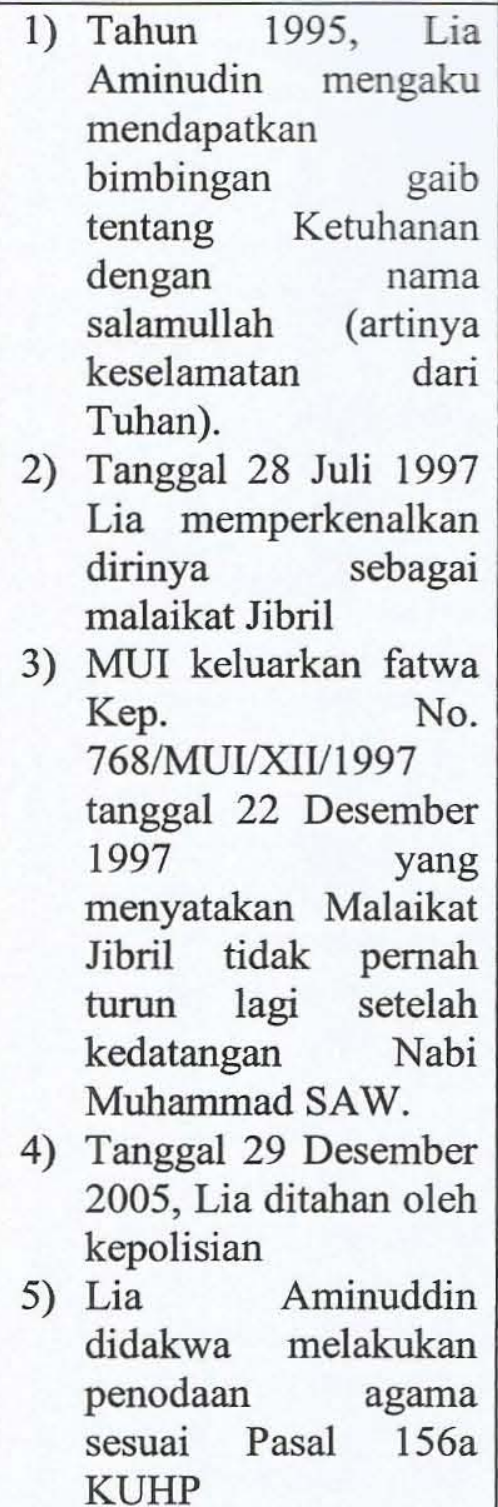 & $\begin{array}{l}\text { Majelis hakim } \\
\text { menilai ia telah } \\
\text { membuat pengakuan } \\
\text { sebagai utusan Tuhan } \\
\text { dan telah melakukan } \\
\text { penafsiran terhadap } \\
\text { beberapa ayat dalam } \\
\text { Al-Quran yang tidak } \\
\text { sesuai kaidah } \\
\text { penafsiran. } \\
\text { Hakim memutus Lia } \\
\text { Aminuddin terbukti } \\
\text { bersalah melanggar } \\
\text { Pasal 156a KUHP }\end{array}$ \\
\hline 3. & $\begin{array}{l}\text { Kasus MGMT } \\
2 \\
\text { pelaku: Ardi } \\
\text { Husein }\end{array}$ & $\begin{array}{lr}\text { 1) Yayasan } & \text { Kanker dan } \\
\text { Narkoba } & \text { Cahaya } \\
\text { Alam } & \text { (YKNCA) } \\
\text { dimana Ardi Husein }\end{array}$ & $\begin{array}{l}\text { - Ardi Husain Pengurus } \\
\text { YKNCA sudah tahu } \\
\text { dalam membuat buku } \\
\text { pasti atau mungkin }\end{array}$ \\
\hline
\end{tabular}




\begin{tabular}{|c|c|c|c|c|}
\hline & & 2) & $\begin{array}{l}\text { sebagai Pembina, } \\
\text { pada bulan Juni } 2004 \\
\text { menerbitkan sebuah } \\
\text { buku "Menembus } \\
\text { Gelap Meuju Terang } \\
2 \text { ". } \\
\text { Buku ini berisi } \\
\text { kompilasi uraian Al- } \\
\text { Quran dan hadist hasil } \\
\text { Ardhi Husein } \\
\text { Tanggal } 16 \text { Mei 2005, } \\
\text { MUI Kabupaten } \\
\text { Probolinggo fatwa } \\
\text { memberikan item } \\
\text { bahwa ada } 60 \text { ing menyesatkan. } \\
\text { yang }\end{array}$ & $\begin{array}{l}\text { akan mendapat reaksi } \\
\text { masyarakat dan para } \\
\text { terdakwa tidak } \\
\text { berupaya } \\
\text { menghindari hal yang } \\
\text { tidak diingini tapi } \\
\text { tidak peduli } \\
\text { Hakim memvonis } \\
\text { bersalah terdakwa } \\
\text { karena melanggar } \\
\text { Pasal 156a KUHP }\end{array}$ \\
\hline 4. & $\begin{array}{l}\text { Kasus: Shalat } \\
\text { dengan bersiul } \\
\text { Pelaku: } \\
\text { Sumardin } \\
\text { Tappayya }\end{array}$ & 1) & 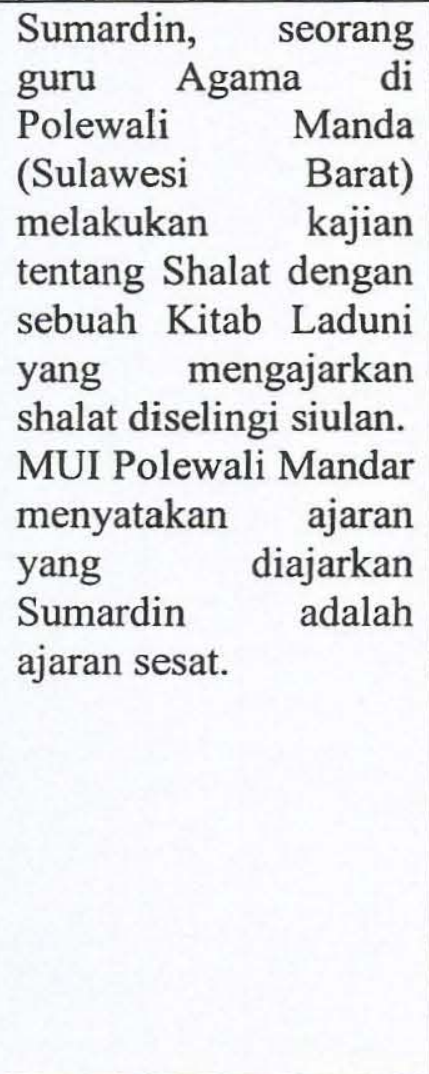 & $\begin{array}{l}\text { Bahwa ajaran dan } \\
\text { kitab Laduni yang } \\
\text { diamalkan dan } \\
\text { diajarkan Sumardin } \\
\text { tersebut } \\
\text { bertentangan dengan } \\
\text { akidah dan syariat } \\
\text { Islam serta bisa } \\
\text { menimbulkan } \\
\text { keresahan } \\
\text { masyarakat karena } \\
\text { ajaran tersebut akan } \\
\text { mendapat } \\
\text { perlawanan dari } \\
\text { orang-orang Islam } \\
\text { yang merasa akidah } \\
\text { dan syariatnya } \\
\text { disalahtafsirkan dan } \\
\text { atau ditafsirkan } \\
\text { sendiri oleh } \\
\text { Sumardin dengan } \\
\text { ajaran }\end{array}$ \\
\hline
\end{tabular}




\begin{tabular}{|c|c|c|c|c|}
\hline & & & & $\begin{array}{l}\text { keselamatannya } \\
\text { Hakim juga } \\
\text { menyesuaikan } \\
\text { putusannya dengan } \\
\text { Pendapat Ketua II } \\
\text { MUI Polewali } \\
\text { Mandar } \\
\text { Terdakwa } \\
\text { dinyatakan bersalah } \\
\text { melanggar Pasal } \\
\text { 156a KUHP dan } \\
\text { Pasal 2 ayat (1) UU } \\
\text { Darurat } 12 / 1951 \mathrm{LN} \text {. } \\
\text { 78/1951 }\end{array}$ \\
\hline 5. & $\begin{array}{l}\text { Kasus Shalat } \\
\text { Dwi Bahasa } \\
\text { Pelaku: } \\
\text { Yusman Roy }\end{array}$ & & $\begin{array}{l}\text { Yusman Roy, pendiri } \\
\text { Yayasan Taqwallah } \\
\text { Pondok I'tikaf Ngaji } \\
\text { Lelaku yang } \\
\text { mengajarkan shalat } \\
\text { dua bahasa. } \\
\text { Pada } 21 \text { Januari 2004, } \\
\text { MUI Kabupaten } \\
\text { Malang mengeluarkan } \\
\text { fatwa nomor Kep. } \\
\text { 02/SKF/MUI.KAB/I/2 } \\
\text { 004 tentang penyiaran } \\
\text { ajaran sesat yang } \\
\text { dilakukan oleh } \\
\text { Yusman Roy. } \\
\text { Pada tanggal } 6 \text { Mei } \\
\text { 2005Kepolisian } \\
\text { Resort Kabupaten } \\
\text { Malang mengeluarkan } \\
\text { surat perintah } \\
\text { penangkapan yang } \\
\text { ditujukan kepada Roy. } \\
\text { Dengan No. pol. }\end{array}$ & $\begin{array}{l}\text { Terdakwa } \\
\text { dinyatakan tidak } \\
\text { bersalah melakukan } \\
\text { penodaan agama } \\
\text { sebagaimana } \\
\text { dimaksudg Pasal } \\
\text { 156a KUHP } \\
\text { Terdakwa } \\
\text { dinyatakan bersalah } \\
\text { melanggar Pasal } 157 \\
\text { KUHP yang isinya } \\
\text { melakukan tindakan } \\
\text { menyiarkan surat, } \\
\text { gambar yang } \\
\text { materinya } \\
\text { menyatakan } \\
\text { permusuhan, } \\
\text { penghinaan terhadap } \\
\text { golongan penduduk } \\
\text { di Indonesia }\end{array}$ \\
\hline
\end{tabular}




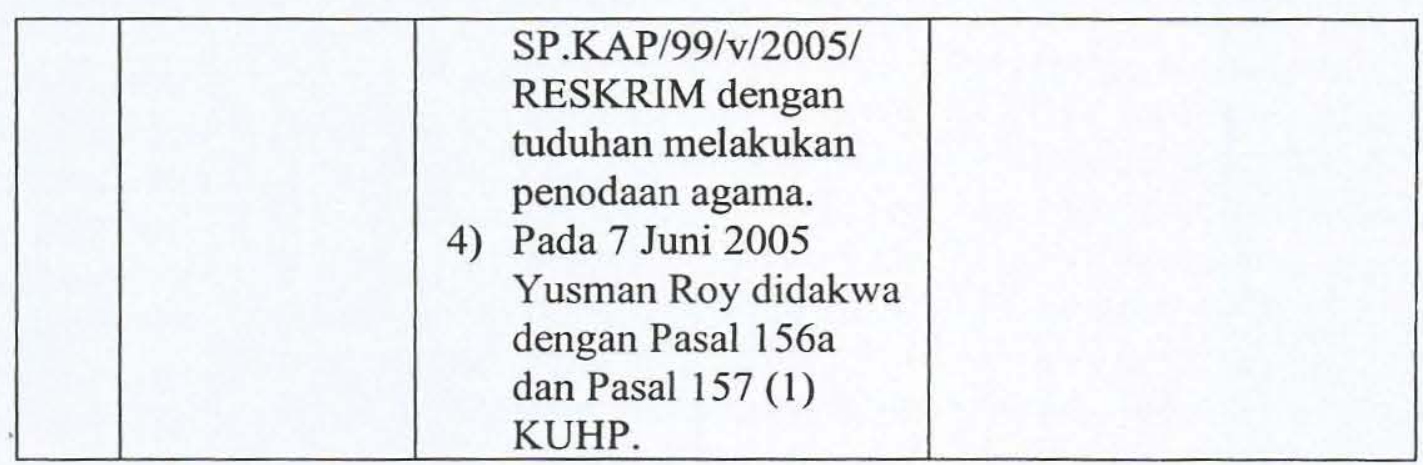

Kelima kasus tersebut disamping menunjukkan kebutuhan pengaturan perlindungan hukum atas agama (ajaran) yang sehat juga menunjukkan posisi strategis lembaga keagamaan. Dari kelima kasus tersebut, hanya pada kasus No. 1 MUI tidak mengeluarkan pernyataan sikap. Ini berarti peranan lembaga keagamaan dalam permasalahan pencegahan penodaan agama sangat penting dan harus terlibat secara aktif. Keterlibatan lembaga keagamaan menjadi kunci meminimalisasi penyalahgunaan Pasal 156a KUHP ketika diterapkan.

Anggapan yang menyatakan bahwa Pasal 156a KUHP sangat berpotensi untuk disalahgunakan sebenarnya berakar pada batasan apakah yang digunakan untuk menentukan suatu ajaran benar atau tidak. Untuk menentukan sampai sejauh mana dan sebatas apa suatu pemahaman/penafsiran sesuai atau tidak sesuai dengan ajaran Agama harus diserahkan pada lembaga keagamaan tiap agama sendiri. Hal tersebut didasarkan pada tugas dasar dari tiap lembaga agama itu untuk membina dan menjaga pertumbuhan pemahaman ajaran agama yang benar. Sebuah kewajiban yang harus dipenuhi oleh lembaga keagamaan setelah melakukan pemeriksaan, pertimbangan, dan putusan lalu memberikan penjelasan tentang hal-hal yang dianggap keliru dan alasan mengapa hal tersebut keliru kepada satu aliran tertentu.

Kasus lain yang serupa dengan itu adalah munculnya aliran Ahmadiyah yang mengajarkan adanya nabi sesudah Nabi Muhammad SAW. Menyikapi kasus ini telah dikeluarkan Keputusan Bersama Menteri Agama, Jaksa Agung dan Menteri Dalam Negeri Republik Indonesia No. 3/2008, No. KEP-033/A/JA/6/2008 dan No. 199 Tahun 2008 tentang Peringatan dan Perintah kepada Penganut, Anggota, dan/atau Anggota Pengurus Jemaat Ahmadiyah Indonesia (JAI) dan Warga Masyarakat yang intinya memberikan peringatan dan perintah bagi JAI untuk menghentikan penyebaran penafsiran dan kegiatan yang menyimpang dari ajaran-ajaran pokok agama Islam. Dengan kata lain Keputusan Bersama ini sama sekali tidak melarang jemaat Ahmadiyah tetapi melarang beberapa tindakan berupa penyebaran penafsiran dan kegiatan yang menyimpang dari pokok-pokok ajaran Agama Islam. Jemaat 
Ahmadiyah tetap diperbolehkan untuk menjalankan hak beragamanya asalkan tidak menyalahi ajaran pokok Agama Islam. Konsekuensi yuridis dari Keputusan Bersama bagi Jemaat Ahmadiyah adalah sepanjang Jemaat Ahmadiyah Indonesia mengaku dirinya sebagai bagian dari Agama Islam harus menyesuaikan diri dengan pokok ajaran Agama Islam yang sudah diakui. Terhadap kasus tersebut keterlibatan Majelis Ulama Indonesia untuk memeriksa dan menilai ajaran yang berlaku dalam jemaat Ahmadiyah sangat diperlukan terlebih alasan-alasan mengapa aliran tersebut tidak sesuai dengan ajaran Islam. Tindakan tersebut seharusnya menjadi perhatian khusus bagi lembaga-lembaga agama ketika memeriksa dan menilai suatu aliran kepercayaan, mengingat masalah agama dan kepercayaan merupakan masalah yang sangat sensitif sehingga harus diselesaikan dengan bijaksana.

\section{UU No. 1/PNPS/1965 dan KUHP}

Pemberlakuan UU No. 1/PNPS/1965 memiliki dampak yuridis bagi Kitab Undang-undang Hukum Pidana. Secara eksplisit UU No. 1/PNPS/1965 mengatur dua macam tindakan yang dilarang yaitu tindakan penyimpangan ajaran agama dan kejahatan agama. Mengenai bentuk tindakan yang pertama sebagaimana Pasal 1 hingga Pasal 3 UU No. 1/PNPS/1965 hanya memberikan bentuk tindakan penyimpangan terhadap ajaran agama yang ada yang merupakan pelanggaran. Hanya saja pengaturan sanksi terhadap tindakan tersebut dibuat secara khusus dan bertahap. Pemberian sanksi tersebut lebih bersifat administratif karena hanya berupa perintah, peringatan keras, pernyataan larangan dan pembubaran (Pasal 2). Sanksi pidana baru diterapkan setelah sanksi administrasi tersebut gagal sehingga diberikan sanksi pidana penjara sebagaimana Pasal 3 UU No.1/PNPS/1965. Bentuk pertama tersebut dapat dikategorikan dalam kejahatan penyimpangan agama. Bentuk kedua diatur dalam Pasal 4 UU No. 1/PNPS/1965 yang mengatur:

Pada Kitab Undang-undang Hukum Pidana diadakan Pasal baru yang berbunyi sebagai berikut:

Pasal 156a

Dipidana dengan pidana penjara selama-lamanya lima tahun barang siapa dengan sengaja di muka umum mengeluarkan perasaan atau melakukan perbuatan: 
Yang pada pokoknya bersifat permusuhan, penyalahgunaan atau penodaan terhadap suatu agama yang dianut di Indonesia;

Dengan maksud agar supaya orang tidak menganut agama apapun juga, yang bersendikan ke Tuhanan Yang Maha Esa.

Ketentuan diatas secara letterlijk memberikan perintah penambahan Pasal 156a pada ketentuan KUHP. Mengingat posisi Pasal 156a KUHP berada dalam Buku II maka jenis tindakan sebagaimana dimaksud dalam Pasal 156a KUHP tergolong sebagai Kejahatan. Pengaturan Pasal 156a KUHP tersebut juga menambah ketentuan hukum pidana di bidang keagamaan yang sebelumnya terdapat beberapa ketentuan hukum yaitu:

\begin{tabular}{|c|c|c|}
\hline Ketentuan Hukum & Hal yang diatur & Sanksi \\
\hline Pasal 175 KUHP & $\begin{array}{l}\text { dengan kekerasan atau ancaman } \\
\text { kekerasan merintangi pertemuan } \\
\text { agama/upacara keagamaan/upacara } \\
\text { penguburan jenazah }\end{array}$ & $\begin{array}{l}\text { pidana penjara maks. } \\
3 \text { minggu atau pidana } \\
\text { denda maks. Rp. } \\
900,-\end{array}$ \\
\hline $6 \mathrm{KUHP}$ & $\begin{array}{lc}\text { sengaja menggangu pertemuan } \\
\text { keagamaan/upacara } \\
\text { keagamaan/penguburan } \\
\text { dengan menimbulkan suara gaduh } \\
\end{array}$ & $\begin{array}{l}\text { pidana penjara maks. } \\
3 \text { minggu atau pidana } \\
\text { denda maks. Rp. } \\
1800,-\end{array}$ \\
\hline Pas: & $\begin{array}{l}\text { - Menertawakan petugas agama } \\
\text { saat bertugas; } \\
\text { - Menghina benda-benda untuk } \\
\text { keperluan ibadat }\end{array}$ & $\begin{array}{l}\text { pidana penjara maks. } \\
4 \text { bulan } 2 \text { minggu } \\
\text { atau pidana denda } \\
\text { maks. Rp. } 1800,-\end{array}$ \\
\hline Pasa & $\begin{array}{l}\text { sengaja merintangi atau menghalangi } \\
\text { jalan masuk atau pengangkutan mayat } \\
\text { ke kuburan }\end{array}$ & $\begin{array}{l}\text { pidana penjara maks. } \\
1 \text { bulan } 2 \text { minggu } \\
\text { atau pidana denda } \\
\text { maks. Rp. } 1800,-\end{array}$ \\
\hline Pasal & $\begin{array}{l}\text { sengaja menodai kuburan atau sengaja } \\
\text { dan melawan hukum merusak tanda } \\
\text { peringatan tempat kuburan }\end{array}$ & $\begin{array}{l}\text { pidana penjara maks. } \\
1 \text { tahun } 4 \text { bulan }\end{array}$ \\
\hline Pasal 180 KUHP & $\begin{array}{l}\text { sengaja dan melawan hukum } \\
\text { menggali atau mengambil jenazah } \\
\text { atau pindahkan jenazah }\end{array}$ & $\begin{array}{l}\text { pidana penjara } 1 \\
\text { tahun } 4 \text { bulan atau } \\
\text { pidana denda maks. } \\
\text { Rp. } 4500,-\end{array}$ \\
\hline Pasal 181 KUHP & menyembunyikan, & pidana penjara maks. \\
\hline
\end{tabular}




\begin{tabular}{|l|l|l|}
\hline & $\begin{array}{l}\text { membawa lari atau menghilangkan } \\
\text { mayat dengan maksud an atau pidana } \\
\text { menyembunyikan kematian atau } \\
\text { kelahirannya }\end{array}$ & $\begin{array}{l}\text { denda maks. Rp., } \\
\text { 4500,- }\end{array}$ \\
\hline
\end{tabular}

Bab V tentang Kejahatan terhadap Ketertiban Umum sebelum penambahan Pasal 156a KUHP terdiri dari 27 macam tindak pidana (tidak termasuk ketentuan hukum yang sudah dihapus atau dipandang tidak perlu menurut Undang-undang No. 1 Tahun 1946) ${ }^{31}$ yang dapat dijabarkan sebagai berikut:

Sistematika BAB V KUHP sebelum penambahan Pasal 156a

\begin{tabular}{|c|c|c|}
\hline Ketentuan Hukum & Jenis Tindak Pidana & Sanksi \\
\hline Pasal 154 KUHP & $\begin{array}{l}\text { Penghinaan terhadap } \\
\text { Pemerintah Indonesia }\end{array}$ & $\begin{array}{l}\text { a. Pidana penjara } \\
\text { maksimal } 5 \text { tahun } \\
\text { b. Pidana denda } \\
\text { maksimal tiga ratus } \\
\text { rupiah }\end{array}$ \\
\hline Pasal 154a KUHP & $\begin{array}{l}\text { Penodaan Bendera dan } \\
\text { Lambang } \\
\text { Republik Indonesia }\end{array}$ & $\begin{array}{l}\text { a. Pidana penjara } \\
\text { maksimal } 4 \text { tahun } \\
\text { b. Denda maksimal tiga } \\
\text { ribu rupiah }\end{array}$ \\
\hline Pasal 1 & $\begin{array}{l}\text { (1) Penghinaan melalui } \\
\text { media terhadap } \\
\text { Pemerintah Indonesia }\end{array}$ & $\begin{array}{l}\text { a. Pidana penjara } \\
\text { maksimal } 4 \text { tahun } 6 \\
\text { bulan } \\
\text { b. Denda maksimal tiga } \\
\text { ratus rupiah }\end{array}$ \\
\hline Pasal 156 KUHP & $\begin{array}{l}\text { Penghinaan } \\
\text { golongan } \\
\text { Indonesia }\end{array}$ & $\begin{array}{l}\text { a. Pidana penjara } 4 \text { tahun } \\
\text { b. Denda maksimal }\end{array}$ \\
\hline Pasal 157 KUHP & $\begin{array}{l}\text { penghinaan melalui media } \\
\text { terhadap golongan Rakyat } \\
\text { Indonesia }\end{array}$ & $\begin{array}{l}\text { a. Pidana penjara } \\
\text { maksimal } 2 \text { tahun } 6 \\
\text { bulan } \\
\text { b. Denda maksimal tiga } \\
\text { ratus rupiah }\end{array}$ \\
\hline Pasal 160 KUHP & Penghasutan & a. Pidana \\
\hline
\end{tabular}

${ }^{31}$ Moeljatno, "Kitab Undang-undang Hukum Pidana", Cetakan Kesembilan belas, (Jakarta: Bumi Aksara, September 1996), hal. 58-67. 


\begin{tabular}{|l|l|l|}
\hline & $\begin{array}{l}\text { melakukan perbuatan } \\
\text { pidana, melakukan } \\
\text { kekerasan penguasa umum } \\
\text { atau tidak menuruti baik } \\
\text { ketentuan undang-undang } \\
\text { atau perintah jabatan }\end{array}$ & $\begin{array}{l}\text { maksimal 6 tahun } \\
\text { benda maksimal tiga } \\
\text { ratus rupiah }\end{array}$ \\
\hline Pasal 161 KUHP & $\begin{array}{l}\text { Penghasutan media } \\
\text { menggunakan menjara } \\
\text { seperti Pasal 160 KUHP }\end{array}$ & $\begin{array}{l}\text { a. Pidana p. Denda maksimal } \\
\text { maksimal } 4 \text { tahun } \\
\text { tiga ratus rupiah }\end{array}$ \\
\hline Pasal 162 KUHP & $\begin{array}{l}\text { Penawaran untuk beri } \\
\text { kesempatan atau sarana } \\
\text { melakukan perbuatan } \\
\text { pidana }\end{array}$ & $\begin{array}{l}\text { a. Pidana penjara } \\
\text { maksimal 9 bulan }\end{array}$ \\
\end{tabular}

Pasal 156a KUHP pada dasarnya merupakan pengaturan khusus dari Pasal 156 KUHP yang mengatur tentang tindak pidana penghinaan terhadap golongan masyarakat di Indonesia. Sianturi menegaskan keberadaan Pasal 156a KUHP tersebut 'telah mengurangi 'keterpakasaan' menggunakan penafsiran secara luas terhadap Pasal 156 KUHP khususnya terhadap objek 'golongan rakyat' yang diperbedakan karena agama". ${ }^{32}$ Keberadaan Pasal 156a KUHP menjadi tanda adanya Kejahatan Agama yang terdiri dari kejahatan terhadap agama dan kejahatan untuk tidak beragama. Penggolongan tersebut didasarkan atas dua macam tindakan yang dilarang menurut Pasal 156a KUHP yaitu:

Sengaja di muka umum mengeluarkan perasaan atau melakukan perbuatan yang pada pokoknya bersifat permusuhan, penyalahgunaan atau penodaan terhadap suatu agama yang dianut di Indonesia;

sengaja di muka umum mengeluarkan perasaan atau melakuka perbuatan dengan maksud agar supaya orang tidak menganut agama apapun juga, yang bersendikan ke-Tuhanan Yang Maha Esa.

${ }^{32}$ S.R. Sianturi, "Tindak Pidana di KUHP Berikut Uraiannya", (Jakarta: Alumni AHM-PTHM, 1983), hal. 295. 
Bentuk pertama disebut sebagai kejahatan terhadap agama karena obyek dari tindakan permusuhan, penyalahgunaan atau penodaan adalah 'agama'. Sianturi menjelaskan ruang lingkup yang dimaksud dengan 'agama' sebagai berikut: ${ }^{33}$

a) Jaminan kemerdekaan bagi tiap-tiap penduduk untuk memeluk agamanya masing-masing,

b) Jaminan kemerdekaan bagi tiap-tiap penduduk untuk beribadat menurut agama dan kepercayaannya itu,

c) Agama (itu sendiri) yang bersendikan Ke-Tuhanan Yang Maha Esa,

d) Ajaran agama yang bersangkutan,

e) Kitab Suci,

f) Lembaga, perhimpunan, golongan sesuatu agama

g) Tempat-tempat ibadah lain dan lain sebagainya.

Dari pendapat tersebut dapat disimpulkan bahwa ruang lingkup 'agama' bukan hanya ajaran agama tetapi juga menyangkut kegiatan menjalankan ibadah dan segala sesuatu yang berhubungan dengan kegiatan agama. Pendapat berbeda dikemukakan Lamintang ketika menjelaskan "agama" dalam Pasal 156a KUHP dengan mengatakan":

Yang dimaksudkan dengan agama di dalam pasal 156a KUHP itu ialah salah satu agama yang diakui di Indonesia, masing-masing yakni agama Hindu, agama Budha, agama Kristen, dan agama Islam. ${ }^{34}$

Agaknya pembentuk UU No.1/PNPS/1965 ketika menyusun Pasal 4 mempunyai pandangan bahwa masalah agama tidak bisa dilepaskan dari kebebasan untuk beragama. Penjelasan Pasal 4 UU No.1/PNPS/1965 secara eksplisit menjelaskan maksud dan tujuan pembentukan Pasal 156a huruf a dalam hal tindakan tersebut ditujukan kepada niat untuk memusuhi atau menghina ${ }^{35}$ suatu agama yang di anut di Indonesia. Terhadap hal tersebut Oemar Seno Adji berpendapat "..., bahwa waktu itu suatu konstruksi hukum tidak merupakan suatu tafsiran "tour de

${ }^{33}$ Ibid., hal. 296.

${ }^{34}$ P.A.F. Lamintang, "Delik-Delik Khusus: Kejahatan terhadap Kepentingan Hukum Negara", (Bandung: SinarBaru, 1987), hal. 464.

${ }^{35}$ K. Wantjik Saleh, "Pelengkap K.U.H.PIDANA: Undang-undang Pidana Baru dan Perubahan K.U.H.Pidana", (Jakarta: Ghalia Indonesia, 1977), hal. 106. 
force" dan dapat dibenarkan, apabila dikatakan bahwa Nabi, Kitab Suci, Pemuka Agama, Lembaga-lembaga Agama, Agamanya sendiri secara essensial tidak dapat dipisahkan dari penganut Agama, dari golongan agama masing-masing, seperti dikatakan oleh Pasal 156 KUHP" ${ }^{36}$ Jika berangkat dari pemahaman bahwa Pasal 156a KUHP merupakan lex specialist dari Pasal 156 KUHP maka memang tidak salah jika istilah 'agama' dimaksudkan pula 'golongan rakyat' dalam hubungannya dengan agama atau "golongan agama". Tetapi jika didasarkan atas Penjelasan Umum UU No. 1/PNPS/1965 yang menjelaskan timbulnya aliran-aliran atau organisasiorganisasi kebathinan/kepercayaan masyarakat yang bertentangan dengan ajaranajaran dan hukum Agama yang terus berkembang dan sangat membahayakan Agama-agama yang ada serta membahayakan persatuan dan kesatuan Nasional-lah yang melatarbelakangi lahirnya Pasal 156a KUHP atau dengan kata lain obyek kejahatan Pasal 156a KUHP adalah agama/ajaran bukan golongan agama secara luas. Seperti ditegaskan Soedarto bahwa "Penpres ini bertujuan untuk melindungi agama terhdap ucapan-ucapan dan praktek-praktek, yang dipandang bisa mengurangi kesucian agama". ${ }^{37}$ Oleh karena itu dapat dikatakan bahwa lahirnya Pasal 156a KUHP sebagai langkah preventif sekaligus reperesif terhadap aliran atau organisasi kebathinan/kepercayaan yang dinilai menodai agama tertentu yang dilindungi di Indonesia. Berdasarkan hal tersebut menurut hemat penulis, istilah agama sebagaimana tercantum dalam Pasal 156a huruf a KUHP hanya menyangkut ajaran agama, Kitab Suci, dan kebebasan beribadah (kegiatan dan tempat ibadah) tidak termasuk di dalamnya Lembaga, perhimpunan, dan golongan sesuatu agama. Ruang lingkup tersebut sekali lagi didasarkan atas pemahaman yuridis terhadap UU No. 1/PNPS/1965 yang membidani lahirnya Pasal 156a KUHP. Pasal 156a KUHP meskipun berada dalam sistematika KUHP tetap harus dilihat latar belakang pembentukan yuridis pada tiap ketentuan hukumnya, seperti halnya KUHP dalam tiap Pasalnya harus dipahami Memorie van Toelichting (Memori Penjelasan) timbulnya ketentuan hukum tersebut dengan tetap menyesuaikannya dengan nilainilai dasar Pancasila.

Bagian kedua dari Pasal 156a huruf b KUHP merupakan kejahatan untuk tidak beragama. Keberadaan Pasal 156a huruf b KUHP tersebut harus dipahami sebagai bentuk perlindungan yang terbatas pada kebebasan agama dan beragama. Dikatakan kebebasan yang terbatas karena Negara Indonesia sebagaimana ditekankan dalam Pancasila merupakan negara yang berdasarkan atas Ke-Tuhanan Yang Maha Esa

\footnotetext{
${ }^{36}$ Oemar Seno Adji, Loc. Cit., hal. 300.

${ }^{37}$ Soedarto, Loc. Cit, hal. 78.
} 
berarti mengakui adanya Tuhan (seperti tampak dalam Pembukaan UUD 1945 "Atas berkat rahmat Allah yang maha kuasa...., susunan Negara Republik Indonesia yang berkedaulatan rakyat dengan berdasarkan kepada Ketuhanan Yang Maha Esa,..."). Selain itu Pasal 29 ayat (2) UUD 1945 juga menekankan bahwa perlindungan terhadap kebebasan untuk beragama (dalam hal ini memilih dan menjalankan ibadah) hanya diberikan kepada orang yang beribadah dan di dalam ajarannya mengakui adanya Tuhan Yang Maha Esa. Secara implisit sebenarnya UUD 1945 melarang dengan keras adanya paham atau aliran kepercayaan ateisme dan komunisme yang tidak mengakui adanya Tuhan Yang Maha Esa. Berdasarkan pemikiran tersebut, Pasal 156a huruf b KUHP memberikan perlindungan bagi setiap orang dari tindakan atau ajaran yang tidak mengakui Ke-Tuhanan Yang Maha Esa. Oleh karena itu Pasal 156a huruf b KUHP merupakan bentuk kejahatan untuk tidak beragama. Hubungan antara Pasal 156 KUHP dengan pembagian Pasal 156a KUHP dapat digambarkan dalam bagan sebagai berikut:

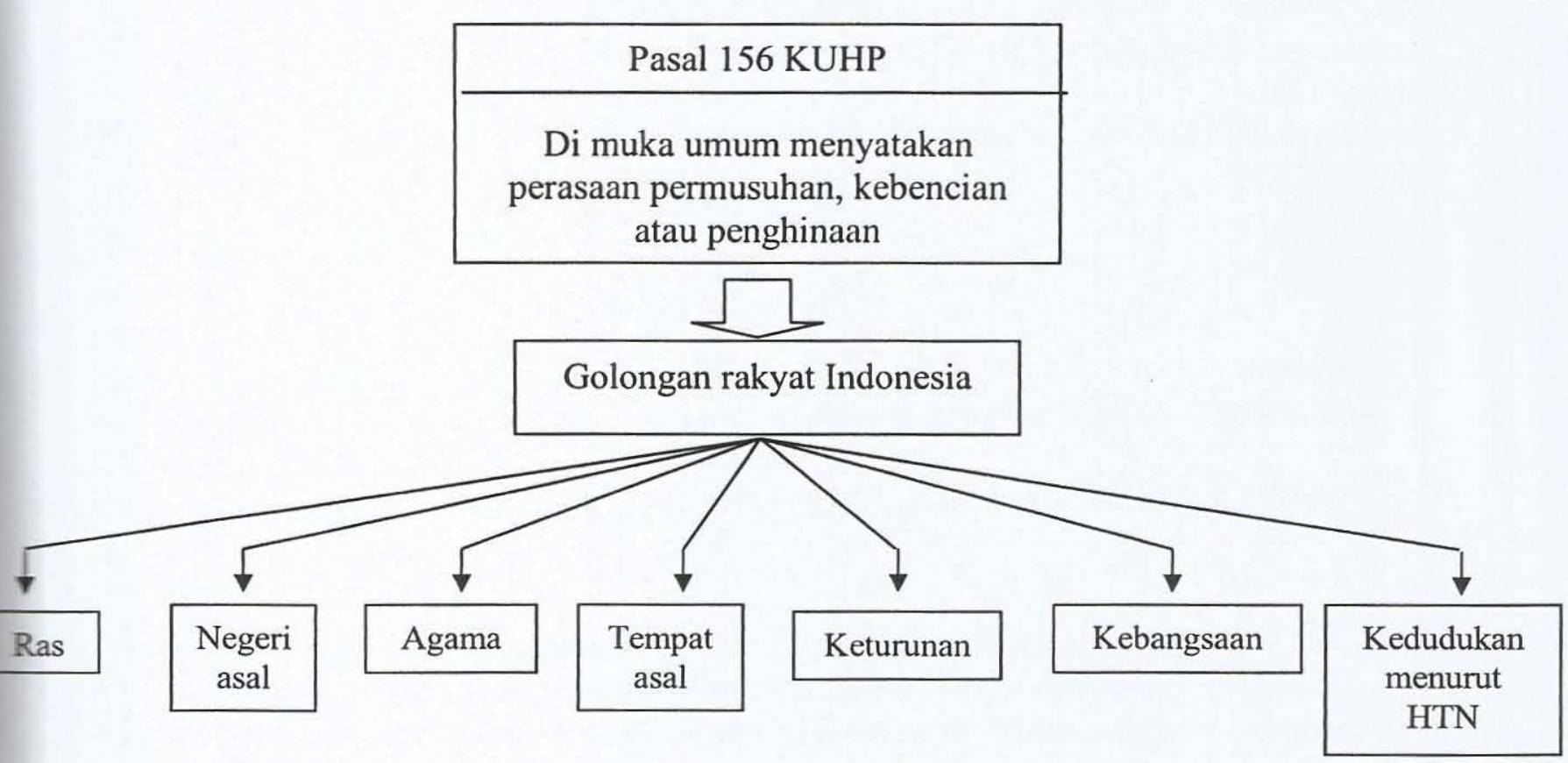




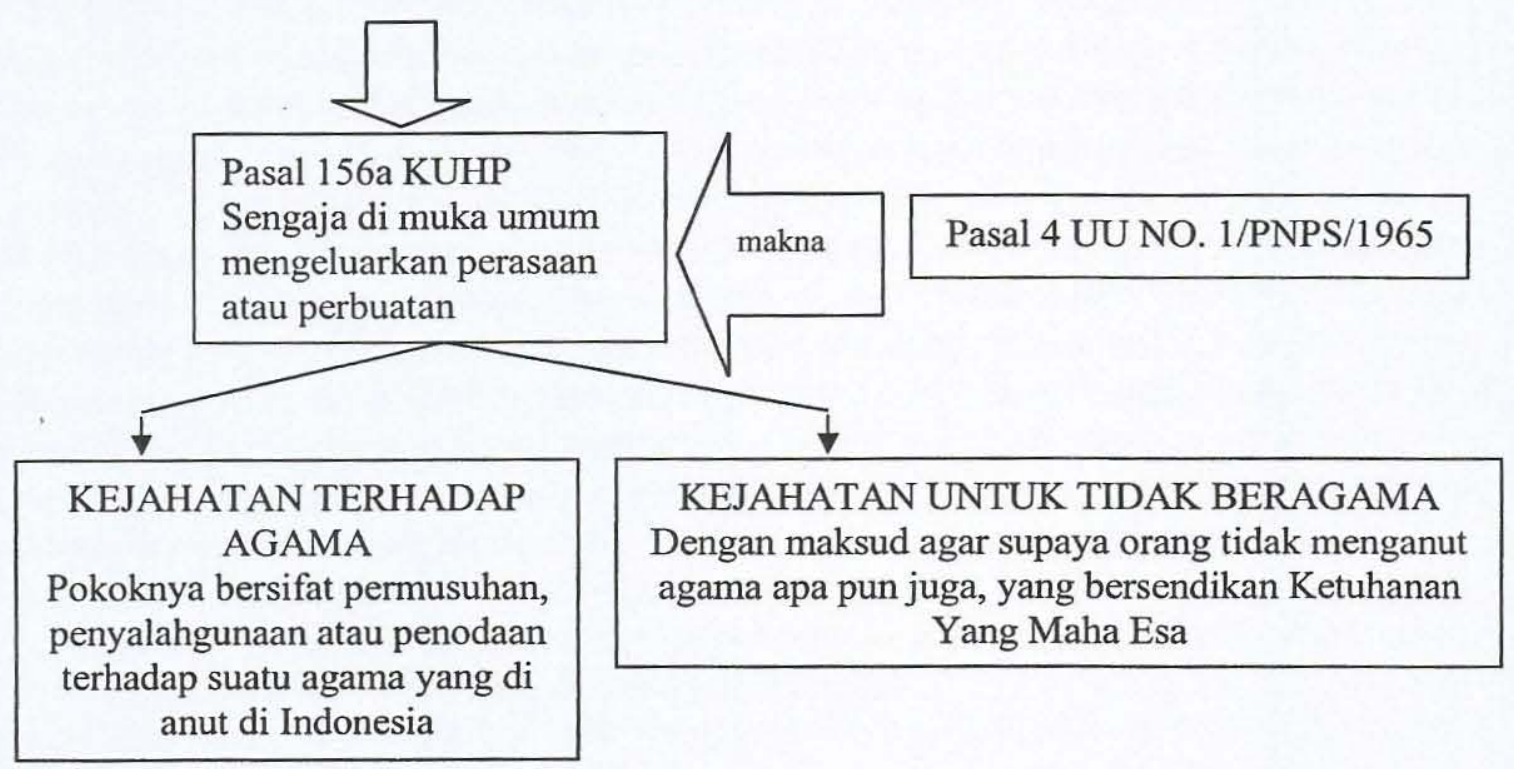

\section{Dampak pemberlakuan UU No. 1/PNPS/1965 bagi Kehidupan Beragama}

Sejak diberlakukan tanggal 27 Januari 1945, UU No. 1/PNPS/1965 merupakan satu-satunya perundang-undangan yang mengatur tentang kehidupan beragama. UU No. 1/PNPS/1965 memberikan perlindungan hukum terhadap kehidupan beragama disebut yang kejahatan terhadap agama. UU No. 1/PNPS/1965 secara letterlijk membatasi perlindungan hukum terhadap agama dari penyimpangan dan penodaan terhadap agama yang dilindungi saja. Agama-agama yang dilindungi adalah Islam, Kristen, Katolik, Hindu dan Khong $\mathrm{Cu}$ sebagaimana ditegaskan dalam Penjelasan Pasal 1 UU No.1/PNPS/1965 sedangkan tentang aliran-aliran kepercayaan seperti Yahudi, Zarazustrian, Shinto, Theoism, dll tetap mendapatkan perlindungan menurut Pasal 29 ayat (2) UUD 1945. Hal tersebut jelas membawa implikasi bagi kehidupan beragama di Indonesia. Implikasi UU No. 1/PNPS/1965 dapat dilihat dari beberapa aspek:

1) Pembatasan seseorang dengan ajaran agamanya

Hubungan seseorang dengan suatu agama di Indonesia didasarkan pada UUD 1945 yang mengatur kewajiban tiap orang untuk beragama. Tidak ada seorang pun yang diberikan satu kebebasan untuk memilih tidak beragama karena pada dasarnya Pasal 29 dan Pasal 28E ayat (1) UUD 1945 menekankan kebebasan untuk memilih agama bukan tidak memilih agama. Hal tersebut didasarkan atas pemikiran bahwa manusia adalah makhluk 
ciptaan yang seharusnya berbakti untuk beribadah dalam sujud sembah kepada Tuhan Yang Maha Kuasa, Pencipta-nya. Pasal 1 dan Pasal 4 UU No.1/PNPS/1965 atau Pasal 156a KUHP juga memberikan batasan kepada seseorang untuk menafsirkan ajaran agamanya dan menjalankan peribadatan agamanya. Artinya, tiap orang tidak diperkenankan melakukan pemahaman menurut sekehendak hatinya melainkan harus merujuk pada ajaran asli dari Kitab Suci masing-masing agamanya. Contoh kasus Lia Eden yang menawarkan aliran baru dalam lingkup agama Islam bahwa Lia Aminudin mengaku mendapatkan bimbingan gaib tentang Ketuhanan dengan nama salamullah (artinya keselamatan dari Tuhan) dan mengaku sebagai nabi sangat bertentangan dengan ajaran agama Islam. Kasus tersebut jelas merupakan penodaan terhadap agama Islam sebagaimana dimaksud dalam Pasal 156a KUHP.

2) Kerukunan agama yang satu dengan agama yang lain

UU No. 1/PNPS/1965 secara tidak langsung juga memberikan pengaturan terhadap relasi antar umat beragama yang sangat rentan konflik terkait dengan masalah agama, kepercayaan dan pelaksanaan ibadahnya. Penyebaran sikap permusuhan, kebencian, dan penghinaan terhadap agama lain sangat dilarang melalui Pasal 156a KUHP meskipun dilakukan dalam rangka pendalaman ajaran agama tertentu jika ditujukan untuk memusuhi, menghina, dan merendahkan agama lain tetap dilarang. Berbeda dengan kajian perbandingan agama yang memliki tujuan pendidikan dan pendalaman, tindakan tersebut tidak termasuk dalam larangan Pasal 156a KUHP.

3) Agama yang dianut menjadi "standar uji" aliran-aliran kepercayaan dan kebathinan yang ada

Meskipun tidak secara eksplisit menyebutkan 6 agama yang diakui sebagai "standar uji" bagi aliran kepercayaan yang ada atau aka nada, UU No.1/PNPS/1965 memberikan penekanan tersebut pada Pasal 1 dan 4 (Pasal 156a KUHP). Bahwa setiap aliran atau tindakan yang tidak sesuai dengan ajaran agama yang sudah diakui merupakan tindakan yang dilarang. Pengaturan tersebut memang sangat potensial disalahgunakan oleh agama yang sudah ada. Agama yang sudah terlebih dahulu ada dengan aliran atau pemahaman yang dimaksud dilindungi oleh hukum. Mengenai aspek keadilan atas hak beragama di dalam hal tersebut sebenarnya terletak pada sampai sejauh mana aliran atau ajaran yang ada benar-benar di dasarkan atas Kitab Suci agama masing-masing. Oleh karena itu, lembaga keagamaan-lah yang 
harus aktif berperan memberikan penjelasan yang memadai kepada aliran pemahaman yang berbeda bila aliran tersebut diterima/sah ataupun ditolak/tidak sesuai dengan ajaran agama. Perlu ditegaskan bahwa sebenarnya tidak hanya 6 agama yang diakui saja yang harus dirujuk oleh aliran-aliran kepercayaan yang ada atau akan ada (baru) melainkan aliran-aliran yang sudah terlebih dahulu ada (terdaftar) seperti Yahudi, Zarazustrian, Shinto dan Theoism (Penjelasan Pasal 1 UU No.1/PNPS/1965) karena memang aliran kepercayaan tersebut tidak dilarang.

4) Aliran kepercayaan baru yang bersendikan Ke-Tuhanan Yang Maha Esa Sebagaimana ditegaskan dalam Penjelasan Pasal 1 UU No. 1/PNPS/1965 bahwa perlindungan hukum diberikan pada agama yang dianut (Islam, Kristen, Katolik, Hindu dan Budha-6 agama) serta agama-agama lain, misalnya Yahudi, Zarazustrian, Shinto, Theoism. Hal yang cukup berbeda sebenarnya diatur dalam penjelasan Pasal 1 UU No. 1/PNPS/1965 tentang perlindungan hukum dari agama yang dianut di Indonesia (6 agama) dan perlindungan hukum dari agama-agama lain. Perlindungan hukum terhadap agama-agama lain memang mendapatkan jaminan melalui Pasal 29 ayat (2) UUD 1945 dan "mereka dibiarkan adanya asal tidak melanggar ketentuanketentuan dalam peraturan ini atau peraturan perundangan lain". Berdasarkan penjelasan tersebut dapat disimpulkan adanya kebijakan pemerintah untuk membatasi aliran kepercayaan atau kebathinan. Kebijakan disini bukanlah pembatasan yang didasarkan atas kepentingan subyektif dari penguasa yang ada tetapi di dasarkan atas UU No.1/PNPS/1965 dan perundang-undangan yang terkait. Pembatasan tersebut dapat dipahami mengingat Indonesia merupakan negara yang berke-Tuhanan Yang Maha Esa sehingga hanya memberikan perlindungan bagi aliran kepercayaan dan kebathinan (agama) yang mengakui adanya Tuhan. Inilah pembatasan pertama yang disebut harus berdasarkan pada Ke-Tuhanan Yang Maha Esa yang mengakui adanya Tuhan.

Pembatasan kedua, jika aliran/kebathinan tersebut berada dalam kelompok agama tertentu maka harus disesuaikan dengan ajaran agama yang sudah ada. Seperti halnya, kasus Sumardin Tappaya yang mengajarkan sholat bersiul harus menyesuaikan diri dengan akidah agama Islam yang tidak mengajarkan tindakan tersebut. Berbeda lagi jika suatu aliran dengan ajarannya menyatakan dirinya sebagai aliran atau agama tersendiri dengan tetap bersendikan Ke-Tuhanan Yang Maha Esa terlepas dari agama yang sudah 
diakui di Indonesia maka terhadap aliran tersebut dilindungi Pasal 29 ayat (2) UUD 1945.

Kedua batasan diatas sebenarnya menegaskan bahwa Indonesia mengakui 6 agama sebagai agama yang dianut oleh rakyat di Indonesia sekaligus menyadari adanya aliran kepercayaan dan kebathinan lain asalkan tetap bersendikan ke-Tuhanan Yang Maha Esa.

\section{Penutup}

Putusan Mahkmah Konstitusi Nomor 140/PUU-VII/2009 tentang Penolakan Pengujian Undang-Undang Nomor 1/PNPS/1965 tentang Pencegahan Penyalahgunaan dan/atau Penodaan Agama semakin menegaskan pentingnya UU No.1/PNPS/1965. Pemberlakuan UU No.1/PNPS/1965 secara yuridis formil memang tidak bertentangan dengan UUD 1945 meskipun dibentuk pada masa demokrasi terpimpin. Hal tersebut diperkuat dari sisi materiil, UU No.1/PNPS/1965 yang memberikan pengaturan tambahan tentang kejahatan terhadap agama. Terdapat 3 bentuk kejahatan terhadap agama di dalam UU No.1/PNPS/1965 yaitu kejahatan penyimpangan ajaran agama, kejahatan terhadap ajaran agama, dan kejahatan untuk tidak beragama. Pengaturan kejahatan bentuk pertama pada dasarnya sudah diatur dalam bentuk kedua, perbedaannya pada bentuk pertama terdapat tahapan penindakan sekaligus sanksi administrasi yang bisa dikenakan pada pelaku. Sebagaimana halnya UU No. 6 Tahun 1969 menegaskan perlunya penyempurnaan UU No.1/PNPS/1965 maka pengkajian sekaligus perumusan kejahatan terhadap agama perlu lebih lanjut dikembangkan agar tidak disalahgunakan oleh pihak-pihak yang ingin menghambat kebebasan beragama. 


\section{Daftar Pustaka}

\section{Buku}

Adji, Oemar Seno. Perkembangan Hukum Pidana dan Hukum Acara Pidana Sekarang dan di masa jang akan Datang, Jakarta: Pantjuran Tujuh, 1983. . Herziening-Ganti Rugi, Suap, Perkembangan Delik, Jakarta: Erlangga, Cetakan Kedua, 1984.

Asshidiqqie, Jimmly. Perihal Undang-Undang, Jakarta: Konstitusi Press, 2006 . Hukum Tata Negara Darurat, Jakarta: RajawaliPers, 2007.

Lamintang, P.A.F. Delik-Delik Khusus: Kejahatan terhadap Kepentingan Hukum Negara, Bandung: SinarBaru, 1987.

Mansoer, Mohammad Tolchah. Pembahasan Beberapa Aspek tentang Kekuasaan-Kekuasaan Eksekutif dan Legislatif Negara Indonesia, Jakarta: Pradnya Paramita, 1983.

Moeljatno. Kitab Undang-undang Hukum Pidana, Jakarta: Bumi Aksara, Cetakan Kesembilan belas, September 1996.

Pringgodigdo, H.A.K. Tiga Undang-Undang Dasar, Jakarta: Pembangunan, Cetakan Keenam, 1989.

Prodjodikoro, Wirjono. Azas-Azas Hukum Tata Negara di Indonesia, Jakarta: Dian Rakyat, Cetakan Kelima, 1983.

Saleh, K. Wantjik. Pelengkap K.U.H.PIDANA: Undang-undang Pidana Baru dan Perubahan K.U.H.Pidana, Jakarta: Ghalia Indonesia, 1977.

Sianturi, S.R. Tindak Pidana di KUHP berikut Uraiannya, Jakarta: Alumni AHM-PTHM, 1983

Sihombing, Herman. Hukum Tata Negara Darurat di Indonesia, Jakarta: Djambatan, 1996.

Soedarto. Hukum Pidana dan Perkembangan Masyarakat: Kajian terhadap Pembaharuan Hukum Pidana. Bandung: Sinar Baru, 1983.

Suny, Ismail. Pergeseran Kekuasaan Eksekutif, Jakarta: Aksara Baru, 1983. 
Wignjosoebroto, Soetandyo. Dari Hukum Kolonial ke Hukum Nasional: Dinamika Sosial Politik dalam Perkembangan Hukum di Indonesia, Jakarta: RajawaliGrafindo, 1994.

\section{JURNAL}

Christianto, Hwian.,"Tata Cara Pelaksanaan Pidana Mati bagi Terpidana Mati dalam Hukum Pidana", Jurnal Mahkamah Konstitusi Vol. 6, Nomor 1 (April 2009): 25-38

Hamidi, Jazim \& Lutfi, "Ketentuan Konstitusional Pemberlakuan Keadaan Darurat Dalam Suatu Negara", Jurnal Konstitusi Volume 6, Nomor 1 (April 2009): 39-78

Soewoto, "Perlindungan Hukum terhadap Agama dan Aliran Kepercayaan", Jurnal Yuridika, No.2, Tahun XI (Maret-April 1996).

\section{Internet}

Sumber Intenet <http://www.mahkamahkonstitusi.go.id/putusan/putusan sidang_Putusan\%20PUU\%20140_Senin\%2019\%20Apri1\%202010.pdf>, diakses tanggal 2 Oktober 2010. 